\title{
Review
}

\section{Integrating Microalgal Production with Industrial Outputs- Reducing Process Inputs and Quantifying the Benefits}

\author{
Joshua J. Mayers, Anna Ekman Nilsson, Elin Svensson, \\ and Eva Albers ${ }^{1}$ \\ ${ }^{1}$ Chalmers University of Technology, Department of Biology \\ and Biological Engineering, Division of Industrial Biotechnology, \\ Göteborg, Sweden \\ ${ }^{2} S P$ Technical Research Institute of Sweden, Food and Bioscience, \\ Ideon, Lund, Sweden \\ ${ }^{3}$ Chalmers University of Technology, Division of Industrial Energy \\ Systems and Technologies, Department of Energy \\ and Environment, Göteborg, Sweden
}

\section{Introduction}

$\mathrm{O}$

ver the past few decades, microalgal biotechnology has seen significant contributions from the fields of biology; engineering and physics relating to cellular physiology and biochemistry; bioreactor design and operation; and biomass downstream processing. High growth rates, no arable land requirement, flexible use of water and nutrient sources, and manipulatable biochemical composition are all reasons to investigate microalgal-derived products. This has resulted in a diverse and attractive array of products, the value of which are increasingly being recognized and pursued by the food, feed, cosmetic, and nutraceutical markets. ${ }^{1}$ However, expansion into production of bulk products with lower market values, i.e., fuel, animal feed, and biomaterials, is limited. Numerous factors limit the potential to fully exploit algae in these market areas-not the least of which is profitability (biomass $\geq \$ 470 / \mathrm{t},{ }^{2,3}$ biodiesel $\left.\geq \$ 3 / \mathrm{gal}\right)^{3,4}$ — but also the energy intensity, resources requirement, and global warming potential (GWP) of production. ${ }^{5-9}$ Commercial production is consequently limited to a relatively small number of species-including Chlorella, Spirulina, Dunaliella, and Haematococcus-and products, including pigments and whole cell supplements. ${ }^{1,10}$ Development of multi-product/service biorefineries, where biomass components are separated to generate several products while using residual nutrient streams and abatement of carbon dioxide $\left(\mathrm{CO}_{2}\right)$ from flue gases, may aid in reducing costs and improving the sustainability of these approaches. ${ }^{5,7,11}$ Although meaningful advances have been made in attaining larger scales of production with high-performing strains, ${ }^{12}$ and more energy efficient and environmentally viable biorefinery practices are in development, ${ }^{7,13}$ it is still likely that these production platforms will operate close to profitability and sustainability margins, with high degrees of uncertainty. . $^{4,9,14,15}$

To develop more feasible algal biorefineries, integration or symbiosis with industrial infrastructure could provide many of the resources required for large-scale production of biomass, including nutrients, water, $\mathrm{CO}_{2}$, and heat. A more sustainable supply of these resources can contribute significantly to decreasing the negative energy balance, GWP, and cost of production. It should subsequently be of the utmost importance to match appropriate outputs (quantity and quality) from different

(C) Joshua J. Mayers, et al., 2016; Published by Mary Ann Liebert, Inc. This Open Access article is distributed under the terms of the Creative Commons Attribution Noncommercial License (http://creativecommons.org/licenses/by-nc/4.0/) which permits any noncommercial use, distribution, and reproduction in any medium, provided the original author(s) and the source are credited. 
industrial or municipal sectors to microalgal biorefineries to realize these benefits. ${ }^{16-18}$

Life-cycle assessments (LCA) and techno-economic analysis (TEA) will also play a key role in shaping the selection and development of sustainable technologies and biorefinery processes. LCA are critical for determining the life-cycle greenhouse gas $(\mathrm{GHG})$ reductions associated with biofuels. In Europe, the Renewable Energy Directive states that by 2020 at least $10 \%$ of energy in transport should be renewable and these fuels need to provide a reduction of GHG emissions of at least $35 \%$. From 2017 the reduction of GHGs should be 50\%, and, from 2018, 60\% compared to fossil fuels. Production of biofuels should not cause destruction of land with high biodiversity or take place on land with high carbon stock. ${ }^{19}$ The Renewable Fuel Standard developed by the United States Energy Independence and Security Act of 2007 requires production of renewable fuels to have at least a $50 \% \mathrm{CO}_{2}$ reduction compared to petroleum fuels to be classed as an advanced biofuel. Comprehensive LCA that consider the whole production chain cradle-to-grave (and land-use change implications) with a consistent methodological approach are subsequently required. ${ }^{20,21}$

Through examination of available literature, a detailed overview of the requirements of these inputs and processes for largescale microalgal production (nutrients, water, $\mathrm{CO}_{2}$, and heat) is presented with considerations on reducing/recycling them. Arguments for the use of low-impact resources from industry in terms of cost and sustainability criteria are presented where appropriate. Furthermore, through a broad consultation of the literature, inconsistencies in reported data for different inputs and processes are highlighted, with an intention to improve future analysis of microalgal production scenarios.

\section{Microalgal Cultivation}

The two most common systems for cultivation of microalgae are open raceway ponds (ORP) and closed photobioreactors (PBR). It is also possible to design algae cultivation systems where ORPs and PBRs are combined. ${ }^{12}$ The location of the production facility has a high impact on biomass production due to differences in solar irradiation, temperature, and rainfall, but the availability of resources such as $\mathrm{CO}_{2}$, nutrients and, energy is also critical for attaining maximal productivities in a given location. ${ }^{22-24}$

The ORP is a simpler construction that requires less financial investment than most PBR designs, but volumetric algae yields are usually lower in the ORP. ${ }^{25,26}$ ORPs are sensitive to contamination and are thus best suited for algae species that grow under extreme conditions. Dunaliella, for example, tolerates high salt concentrations, and Spirulina can tolerate high alkalinity. ${ }^{1}$ ORPs are also unsuitable for locations with high rainfall.

The advantage of closed PBRs over ORPs is the more controlled growth environment. PBRs exhibit better contamination avoidance and higher volumetric productivities due to the greater surface-to-volume ratio. The major disadvantages are the higher investment and operating costs. Several varieties of photobioreactor designs exist, with tubular PBR, flat-panel PBR, and bubble-column PBR the most common designs. PBRs can, however, be relatively simple constructions as well, such as hanging plastic bags. ${ }^{27}$

\section{EXPECTED BIOMASS OUTPUT}

There are large variations in the biomass productivity of different algae production systems described in the literature (Table 1). ${ }^{4,27}$ The theoretical maximum photosynthetic efficiency of microalgae (the percentage of incident light energy absorbed and fixed as biomass) has been calculated to be between $8-12 \%$ of incident irradiance, but growth trials fall a long way from obtaining these values (Table 1). ${ }^{28,29}$ The inability to attain predicted yields of biochemical energy from incident irradiance is likely to be a critical factor limiting cost-effective and energy-efficient production of microalgal biomass on a large-scale. Achieving higher photosynthetic efficiencies should subsequently be considered a critical aim in photobioreactor location, design, and operation. ${ }^{30}$ Determining the photosynthetic efficiency should also be prioritized during large-scale trials to generate a more thorough understanding of factors impacting this parameter, as well and for aiding development of effective areal growth models. ${ }^{31}$

\section{ELECTRICITY REQUIREMENTS}

The energy required for mixing in an ORP depends on depth, ${ }^{35}$ which in turn can determine the biomass productivity. ${ }^{36}$ A deeper pond has the potential to improve areal productivity, possibly at the expense of volumetric productivities, ${ }^{36}$ but it also increases the energy needed for mixing; these factors need to be optimized to achieve low energy consumption per unit of biomass produced. Paddlewheels are typically used for mixing ORPs, and their energy consumption is dependent on several factors, including pond depth, liquid velocity, and presence and number of baffles. ${ }^{35}$ There is subsequently a wide range of values used for paddlewheel energy consumption costs in the literature, $18-288 \mathrm{MJ} / \mathrm{ha} /$ $\mathrm{d},{ }^{6,7,37,38}$ which equates to $0.25-4.04 \mathrm{MJ} / \mathrm{kg}$ of dry weight (DW) biomass produced in some studies. ${ }^{6,15,37,38}$ However, in Rogers et al., the energy demand of the paddlewheels in a $0.3 \mathrm{~m}$ deep pond was predicted to be 190-630 MJ/ha/d (based on supplier data), but was actually measured to be $7,050 \mathrm{MJ} / \mathrm{ha} / \mathrm{d}(470 \mathrm{MJ} / \mathrm{kg}$ DW) when operated, representing a significant proportion of the total energy required for production. ${ }^{39}$

Gas injection into the ponds is also a costly process $(0.09-0.15$ $\mathrm{MJ} / \mathrm{kg} \mathrm{DW}){ }^{37,40,41}$ Taelman et al. calculated an energy input of 803.1 MJ/d for mixing, pumping, and gas injection into two ponds, each with a depth of $0.6 \mathrm{~m}$ and a total area of $500 \mathrm{~m}^{2}(1,885$ $\mathrm{MJ} / \mathrm{kg} \mathrm{DW}$ ), with the operation of the air blower contributing most significantly to this cost. ${ }^{9}$ These energy requirements are significantly higher than many reported values, but were measured during pilot-plant operation rather than predictions. According to Brentner et al., the electricity required for aeration of an ORP is $43.2 \mathrm{MJ} / \mathrm{ha} / \mathrm{d}\left(0.02 \mathrm{MJ} / \mathrm{m}^{3} / \mathrm{d}\right) .{ }^{42}$ Lardon et al. assumed an energy demand of $0.08 \mathrm{MJ} / \mathrm{kg} \mathrm{CO}_{2}$ injected based on literature data. ${ }^{43}$ In a study by Mendoza et al., the power consumption of different gas diffusers in an ORP was measured. ${ }^{44}$ Aeration using a membrane tube diffuser had a power consumption of up to 150 $\mathrm{W}$. Aeration using a porous tube diffuser consumed $70 \mathrm{~W}$, while a plate diffuser consumed $56 \mathrm{~W}$. The gas-transfer efficiency increased linearly with decreased bubble size, and a porous tube diffuser was considered the best choice. ${ }^{44}$ Other attempts to increase energy efficiency in the operation of ORPs include substituting the paddlewheel for more efficient propellers, ${ }^{32}$ sump 
Table 1. Examples of Literature Data for Volumetric and Areal Algae Production Yields in Outdoor Pilot and Large-Scale ORPs and PBRs

\section{BIOMASS PRODUCTIVITY}

VOLUMETRIC

$\left(\mathrm{kg} \mathrm{DW} / \mathrm{m}^{3} / \mathrm{d}\right)$
AREAL

(g DW/m $\left./ \mathrm{m}^{2} / \mathrm{d}\right)$
PHOTOSYNTHETIC

EFFICIENCY $(\%)$
COMMENTS ORPs

\begin{tabular}{l|c|c|c|l}
\hline $\begin{array}{l}\text { Tetraselmis suecical } \\
\text { Nannochloropsis }\end{array}$ & - & $8.37-8.9 / 10.44-14.1$ & - & Florence, Italy \\
\hline Scenedesmus sp. & 0.09 & $17.5 \pm 0.8$ & - & 10 -month average. Southern Spain \\
\hline Nannochloropsis gaditana & 0.20 & 22.4 & - & Southern Spain, Summer \\
\cline { 2 - 5 } & 0.09 & 10.3 & - & Southern Spain, Winter \\
\hline Scenedesmus and Chlorella (mix) & 0.09 & 11.5 & - & Yearly average. Lelystad, Netherlands \\
\hline Scenedesmus acutus & 0.09 & $6.6 \pm 2.3$ & $0.3-0.7$ & Arizona, US \\
\hline Nannochloropsis sp. CCAP 211/78 & $0.03-0.08$ & $9.7-14.0$ & $1.1-1.5$ & Wageningen, Netherlands, Summer \\
\hline
\end{tabular}
PBRs

\begin{tabular}{l|c|c|c|l|l}
\hline Scenedesmus acutus & - & $19.0 \pm 0.6$ & $1.3-2.2$ & Flat-panel. Arizona, US \\
\hline Nannochloropsis gaditana & 0.59 & 15.4 & - & $\begin{array}{l}\text { Horizontal tubular. Southern Spain, } \\
\text { Winter }\end{array}$ \\
\hline Nannochloropsis sp. CCAP 211/78 & $0.57-0.71$ & $19-24$ & $2.4-4.2$ & $\begin{array}{l}\text { Vertically stacked horizontal tubular. } \\
\text { Wageningen, Netherlands, Summer }\end{array}$ \\
\hline Nannochloropsis sp. CCAP 211/78 & $0.65-0.85$ & $12-15$ & $1.5-1.8$ & $\begin{array}{l}\text { Horizontal tubular. Wageningen, } \\
\text { Netherlands, Summer }\end{array}$ \\
\hline Nannochloropsis sp. CCAP 211/78 & $0.9-1.20$ & $20-27.5$ & $2.7-3.8$ & $\begin{array}{l}\text { ProviAPT flat-panel. Wageningen, } \\
\text { Netherlands, Summer }\end{array}$ \\
\hline Desmodesmus sp. & 0.289 & 43.3 & - & Horizontal tubular. Hawaii, Summer \\
\hline
\end{tabular}

ORPs, open raceway ponds; PBRs, photobioreactors.

configuration for improved gas transfer, ${ }^{33}$ and implementing airlift mixing to improve gas transfer in the ponds. ${ }^{45}$

Predicting the cultivation energy requirement for PBRs is dependent upon the geometry of the system. Flat-plate PBRs require energy for only air/ $\mathrm{CO}_{2}$ injection, whereas in tubular PBRs energy is needed for both aeration and pumping the culture liquid. The need for pumping in a tubular PBR could limit the species that can grow in a tubular PBR, as some are inherently sensitive to the shear stress caused by use of centrifugal pumps. ${ }^{27}$ Several studies use the value $4.6 \mathrm{MJ} / \mathrm{m}^{3} / \mathrm{d}$ for the electricity requirement of flat-panel PBRs, whereas the energy consumption for tubular PBRs has been estimated to be $173-584 \mathrm{MJ} / \mathrm{m}^{3} / \mathrm{d} .{ }^{42,46}$ Jorquera et al. assumed an electricity input of $53 \mathrm{~W} / \mathrm{m}^{3}$ for flat-plate and $2,500 \mathrm{~W} / \mathrm{m}^{3}$ for tubular. ${ }^{46}$ In pumped systems where aeration is not required for mixing, aeration/ $\mathrm{CO}_{2}$ injection can be avoided during the dark cycle. Huntley et al. reported the use of a tubular system with a low-pressure, high-volume airlift that had an energy requirement of $0.31 \mathrm{MJ} / \mathrm{m}^{3} / \mathrm{d}(824 \mathrm{MJ} / \mathrm{ha} / \mathrm{d})^{7,12}$ — significantly lower than other airlift systems. ${ }^{47,48}$

In addition to electricity consumption for mixing and aeration, growing algae in high latitudes may require additional electricity inputs for lighting for large proportions of the year. The provision of the right amount and quality of incident light is critical in achieving high growth rates and consistent production. Light-emitting diodes are increasingly being used to illuminate cultures for lab-scale experiments $^{49}$ and some large-scale applications. ${ }^{50,51}$ However, additional lighting will come at a heavy price in terms of investment and operational costs. According to Sevigné Itoiz et al., the energy required for illumination of an indoor bubble column PBR system with fluorescent lamps was $158-167 \mathrm{MJ} \mathrm{kg} / \mathrm{DW} .{ }^{52}$ Blanken et al. predicted that the use of artificial illumination would add $\$ 12.30$ $19.10 / \mathrm{kg}$ DW to the cost of production, ${ }^{49}$ limiting their use to just the production of biomass for high-value products that are not so sensitive to investment costs or energy balances, such as astaxanthin from Haematococcus pluvialis $(\$ 15,000 / \mathrm{kg}$ pigment $) .{ }^{1}$

Other electricity requirements during production include pumping of the culture between different growth systems (inoculum to main system) and downstream processing equipment. Energy requirements pertaining to dewatering and harvesting are beyond the scope of this review, but several excellent texts are available. ${ }^{53,54}$ Processes relating to heating and drying of biomass are considered below. 


\section{Resource and Energy Requirements for Biomass Production \\ CONSIDERATION OF NUTRIENT REQUIREMENTS}

LCA and resource assessments primarily consider the inputs of nitrogen $(\mathrm{N})$ and phosphorus $(\mathrm{P})$ when developing microalgal cultivation scenarios. However, there is a great deal of uncertainty in the literature as to the true nutritional requirement of cultivation, significantly skewing the environmental impact and cost associated with their input, especially if they are derived from fertilizers.

The elemental composition of microalgal biomass can be used to determine the nutrient requirement of cultivation, but is lacking in nearly $25 \%$ of LCA. ${ }^{20}$ Microalgae are typically $1.5-10 \%$ of their DW as $\mathrm{N}^{55,56}$ and $0.1-3 \% \mathrm{DW}$ as P. ${ }^{57,58} \mathrm{~A}$ number of assessments use the Redfield elemental molar ratio of $\mathrm{C}_{106}: \mathrm{N}_{16}: \mathrm{P}_{1}$ and a $\mathrm{C}$ content of $50 \% \mathrm{DW}$ to determine the $\mathrm{N}$ and $\mathrm{P}$ requirement, ${ }^{43,59,60}$ resulting in $8.8 \% \mathrm{~N}$ and $1.2 \% \mathrm{P}$, or $88 \mathrm{~g} \mathrm{~N}$ and $12 \mathrm{~g} \mathrm{P}$ per $\mathrm{kg}$ of biomass. This approach may be appropriate in some circumstances, but practitioners must consider that this ratio has been shown to be non-representative for a large number of species and varies significantly. ${ }^{58,61}$ What is additionally worrying is that many studies using the Redfield ratio do not understand the link between nutrient supply and biochemical composition, in particular, lipid content. This results in lipid contents being assigned to biomass that is highly unlikely given the cultivation conditions/ nutrient status. There has to be an awareness that the nutrient concentration of the growth medium has a substantial impact upon biochemical composition, i.e. the biomass $\mathrm{N}$ (or P) content is intrinsically linked to the lipid content. ${ }^{55,58}$

Nutrient starvation of microalgae is a substantially researched area of the algal field, with $\mathrm{N}$-limitation in particular being a common practice to bring about a change in composition. The exhaustion of a key nutrient results in the cessation of cell division due to inability to synthesize key macromolecules, such as proteins, DNA, or RNA. Despite this decrease in growth rate, photosynthetic C-fixation proceeds, albeit at a lower rate, resulting in an accumulation of $\mathrm{C}$-enriched compounds such as lipids (triglycerides) or carbohydrates. ${ }^{62}$ There is subsequently a breadth of information available pertaining to changes in biochemical composition in relation to nutrient supply, and this should be more carefully considered in LCA/TEA.

In some cases during LCA/TEA, a high lipid content is assigned to biomass (also with high $\mathrm{N}$ requirements; Table 2), but the negative effect on biomass productivity associated with higher lipid contents under nutrient starvation is not considered. This type of inventory results in the conclusions being heavily skewed to the positive regarding many aspects of the process assessment and energy balance. In a recent study, Collet et al. found that only $20 \%$ of the LCAs examined considered the implications of $\mathrm{N}$-starvation and its effect on productivity. ${ }^{20}$ This is not to say that there are not good examples in the literature. Lardon et al. considered two biochemical compositions of Chlorella biomass, one with sufficient N (5\% DW N, 18\% DW lipid) and low N (1.1\% DW N, 39\% DW lipid) based on published compositions and found that producing high lipid biomass significantly improves the energy balance of biodiesel production. ${ }^{43}$ The use of accurate composition data is obviously im- portant in determining the correct quantities of nutrient inputs and product composition for a given cultivation scenario, leading to more accurate representation of the whole process with regards to cost, energy input, and environmental impact.

Energetics and implications of fertilizer use. Common N- and Pcontaining agricultural fertilizers have similar production energy demands (ammonium nitrate $=51 \mathrm{MJ} / \mathrm{kg} \mathrm{N}$, triple super phosphate, $\left.\mathrm{Ca}\left(\mathrm{H}_{2} \mathrm{PO}_{4}\right)_{2}=58.9 \mathrm{MJ} / \mathrm{kg} \mathrm{P}\right)$, but since $\mathrm{N}$ makes a greater contribution to the biomass, it represents a more significant impact on the energy balance of cultivation. If $88 \mathrm{~g} \mathrm{~N}$ and $12 \mathrm{~g} \mathrm{P}$ are required to produce $1 \mathrm{~kg}$ of biomass, the energy input would be approximately $4.5 \mathrm{MJ}$ for $\mathrm{N}$ and $0.71 \mathrm{MJ}$ for $\mathrm{P}$. Assuming a biomass energy content of approximately $24 \mathrm{MJ}$, this would result in $\mathrm{N}$ and P inputs representing $18.7 \%$ and $3 \%$ of the energy inherent in the biomass, respectively. The global warming potential associated with the production of these fertilizers is also significant, amounting to 0.82 and $0.04 \mathrm{~kg} \mathrm{CO}_{2-}$ equivalents for the required $\mathrm{N}$ and $\mathrm{P}$ inputs for $1 \mathrm{~kg}$ biomass, respectively. Considering that approximately $1.5-2.0 \mathrm{~kg} \mathrm{CO}$ are required to produce $1 \mathrm{~kg}$ biomass $(40-55 \% \mathrm{C}$ ), fertilizer use, in particular N-based fertilizers, makes a significant negative contribution to the net $\mathrm{CO}_{2}$ emissions associated with cultivation. Decreasing or removing the use of fertilizers in large-scale microalgal culture is hence a critical priority for the sustainable production of bioenergy or chemical feedstocks if favorable energy and emissions balance is to be attained.

Beyond issues regarding the cost and environmental impacts of fertilizer use, two studies have highlighted how large-scale microalgal cultivation could impact fertilizer use in the US. The US Energy Independence and Security Act states that by 2022 , advanced biofuel production - those with $<50 \%$ GWP of fossil fuels-should reach 79 billion L/year. To meet even $23 \%$ of this requirement ( 5 billion L/y), Canter et al. calculated that microalgal cultivation would require $20-22 \%$ of the total $\mathrm{N}$ and $12-18 \%$ of the total $\mathrm{P}$ used in the US during $2013 .{ }^{8}$ The increase in $\mathrm{N}$ demand for microalgal cultivation will lead to increased prices, with significant impacts on other sectors, in particular, agriculture. With regards to $\mathrm{P}$ fertilizers, there is typically an annual surplus of production in the US, of which microalgal cultivation would consume $19-30 \% .{ }^{63}$ Hence, it is imperative to identify suitable residual nutrient sources or maximize the conservation and recycling of nutrients within a biorefinery. Rösch et al. and Canter et al. provide more indepth reviews of the recovery of nutrients from different microalgal fractions. ${ }^{8,64}$

Considerations for the use of waste nutrients for biomass production. Understanding nutrient requirements for a given species (in a given PBR/environment) is also critical in the utilization of waste nutrient sources. There are now numerous studies investigating the use of nutrients from different wastewater (WW) or residual streams for the cultivation of microalgae. ${ }^{65,66}$ The content and ratio of nutrients $(\mathrm{N}: \mathrm{P})$ in WW can vary significantly between sources, as well as temporally from a single source. This could ultimately determine the biomass productivity and feasibility of using this source. A high N:P ratio 
Table 2. Summary of LCA Nutrient Input Data for Production of $1 \mathrm{~kg}$ Dry Algal Biomass, the Types of Fertilizers Used, and Values for Lipid Content and Higher Heating Values (HHV), if Reported

\begin{tabular}{|c|c|c|c|c|c|c|c|c|c|}
\hline SPECIES & $\begin{array}{c}\mathrm{N} \\
(\mathrm{g} / \mathrm{kg} \mathrm{DW})\end{array}$ & N FORM & $\begin{array}{c}P \\
(g / k g ~ D W)\end{array}$ & $\begin{array}{c}P \\
\text { FORM }\end{array}$ & $\begin{array}{c}K \\
(g / k g ~ D W)\end{array}$ & K FORM & $\begin{array}{c}\text { LIPID } \\
(\mathrm{g} / \mathrm{kg} \text { DW) }\end{array}$ & $\begin{array}{c}\text { HHV } \\
(\mathrm{MJ} / \mathrm{kg} \\
\mathrm{DW})\end{array}$ & REFERENCE \\
\hline Generic algae marine & 44 & Ammonia & 9.5 & TSP & 13.4 & Potassium sulphate & 500 & 25.8 & 41 \\
\hline Chlorella vulgaris & 46 & Calcium nitrate & 9.9 & SSP & 8.2 & Potassium chloride & 175 & $19.3^{e}$ & 43 \\
\hline C. vulgaris & 10.9 & Calcium nitrate & 2.4 & SSP & 2 & Potassium chloride & 385 & $24.9^{e}$ & 43 \\
\hline Generic alga freshwater & 73 & Urea & 19.4 & SSP & - & - & - & 24 & $38^{\mathrm{a}}$ \\
\hline C. vulgaris & 24 & Ammonium nitrate & 2.2 & TSP & - & - & 40 & - & 48 \\
\hline C. vulgaris & 61 & Ammonium sulphate & 8.1 & SSP & 6.6 & Potassium chloride & - & - & 37 \\
\hline C. vulgaris & 33 & - & 23.2 & - & - & - & - & - & 76 \\
\hline Scenedesmus dimorphus & 82 & Ammonium nitrate & 10 & $\begin{array}{l}\text { Calcium } \\
\text { phosphate }\end{array}$ & - & - & 250 & - & $42^{c}$ \\
\hline Haematococcus pluvialis & 60 & $\begin{array}{l}\text { Potassium } \\
\text { Nitrate }\end{array}$ & 8.3 & SSP & - & - & 250 & - & $59^{b}$ \\
\hline Nannochloropsis sp. & 150 & - & 20 & - & - & - & 500 & - & 77 \\
\hline Generic algae freshwater & 38.3 & $\mathrm{MAP}+$ urea & 12.8 & MAP & - & - & $130-260$ & - & $78^{b}$ \\
\hline Generic algae marine & 42.8 & $\mathrm{MAP}+$ urea & 12.8 & MAP & - & - & $170-320$ & - & $78^{b}$ \\
\hline Generic algae freshwater & 90 & Ammonia & 13 & $\begin{array}{l}\text { Phosphoric } \\
\text { acid }\end{array}$ & - & - & $500^{d}$ & - & $79^{\mathrm{a}}$ \\
\hline Nannochloropsis sp. & 70 & & 10 & - & 10 & - & - & $20.1^{e}$ & $80^{c}$ \\
\hline Generic algae freshwater & 82 & - & 12.8 & - & - & - & $200-500$ & 21 & $16^{\mathrm{b}}$ \\
\hline Nannochloropsis sp. & 82 & Ammonium nitrate & 7 & $\begin{array}{l}\text { Calcium } \\
\text { phosphate }\end{array}$ & - & - & 29 & - & $14^{c}$ \\
\hline
\end{tabular}

$\mathrm{SSP}$, single super phosphate (mixture of $\mathrm{Ca}\left(\mathrm{H}_{2} \mathrm{PO}_{4}\right)_{2}$ and $\left.2 \mathrm{CaSO}_{4}, 9 \% \mathrm{P}\right) ; \mathrm{TSP}$, triple super phosphate $\left(\mathrm{Ca}_{2}\left(\mathrm{H}_{2} \mathrm{PO}_{4}\right)_{2} \cdot \mathrm{H}_{2} \mathrm{O}, 25 \%\right.$ P); MAP, monoammonium phosphate $\left(\mathrm{NH}_{4} \mathrm{H}_{2} \mathrm{PO}_{4}, \sim 12 \% \mathrm{~N}, \sim 23 \% \mathrm{P}\right)$; DAP, diammonium phosphate $\left(\left(\mathrm{NH}_{4}\right)_{2} \mathrm{HPO}_{4} \sim 21 \% \mathrm{~N}, \sim 26 \% \mathrm{P}\right)$.

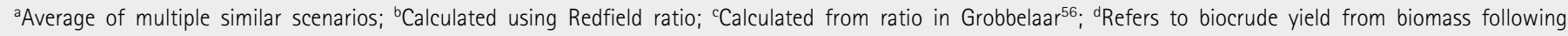
hydrothermal liquefaction; ${ }^{e}$ Converted from lower heating value to HHV by multiplying by $1.11^{80} ;{ }^{\text {f }}$ Cites nutrient usage data from paper that had uncorrected values.

is likely to lead to a P-limitation, decreased growth rates, and effects on the biochemical composition. ${ }^{58}$ Many systems analyses optimistically assume that nutrient requirements can be met quite satisfactorily by nutrients contained in WW and do not consider that essential nutrients might not be balanced or too dilute/ concentrated. For instance, Handler et al. found that the study of Clarens et al. had incorrectly assumed that, based on the nutrient contents of three waste sources, all $\mathrm{N}$ and $\mathrm{P}$ requirements for algal cultivation would be met, whereas in fact only one of the three had sufficient nutrients. ${ }^{38,67}$ Furthermore, it was recently found that an anaerobic digester effluent (N:P 99:1) could supply $100 \%$ of $\mathrm{N}$ for microalgal growth, but additional $\mathrm{P}$ was required to provide an appropriate ratio of $\mathrm{N}: \mathrm{P}$ ratio $(\mathrm{N}: \mathrm{P} 32: 1) .{ }^{68}$

An additional benefit for the utilization of nutrients is that microalgal cultivation will replace traditional biological nutrient removal (BNR) systems in WW treatment works, which are inherently energy intensive due to electricity and chemical consumption (in particular, external C-sources used in the denitrifica- tion process, such as methanol and acetic acid). ${ }^{69}$ The avoidance of these processes through microalgal cultivation will generate credits equal to the quantity of traditional BNR replaced. Sturm and Lamer suggest that, from their inclusion of BNR credits, nutrient removal accounts for $24-55 \%$ of the energy gained in the system. ${ }^{70}$ Handler et al. also calculated the BNR credit for treatment of municipal waste and found that it was equal to approximately $4.2 \mathrm{MJ}$ of electricity and $0.31 \mathrm{~kg}$ of methanol $(<10 \mathrm{MJ})$ per kg of DW produced, which was greater than the electricity requirement of cultivation in this scenario. ${ }^{11}$ The exact amount of energy and resources saved is dependent upon local WW treatment processes and water nutrient release legislation.

Besides these benefits, however, another often neglected factor needs to be considered. Most WW streams are rich in ammonium ions, which are in a chemical equilibrium with ammonia that can be lost to the environment via volatilization. ${ }^{71}$ These emissions can subsequently contribute to indirect $\mathrm{N}_{2} \mathrm{O}$ emissions, which is a potent GHG and has impacts on air quality, 
aerosol formation, and health human, and increases eutrophication through deposition of $\mathrm{N}$ in water bodies. ${ }^{72}$ Yuan et al. recently estimated $\mathrm{N}$ loss via volatilization to be $4 \%$ of input, ${ }^{73}$ but in an empirical ORP trial, $40 \%$ of ammonium was volatilized ( $\left.>500 \mathrm{mg} \mathrm{NH}_{4}{ }^{+} / \mathrm{L} / \mathrm{d}\right)$ when operated semi-continuously for $30 \mathrm{~d} .{ }^{71}$ High dissolved ammonia concentrations can be toxic to cells, ${ }^{74}$ so nutrient sources may require dilution before use, but loss of $\mathrm{N}$ through volatilization will also increase the $\mathrm{N}$ requirement of the system and result in decreased $\mathrm{N}: \mathrm{P}$ ratios $(\mathrm{N}-$ limited conditions). This is critical if nutrient removal from WW is an intended aim of cultivation, as it may lead to incomplete $\mathrm{P}$ assimilation. Maintaining the culture $\mathrm{pH}$ below 9 ( $\mathrm{pKa}$ of ammonia) prevents shifts in this equilibrium, as ammonium is the major form in both freshwater and seawater at $\mathrm{pH}$ of 7 at 15$25^{\circ} \mathrm{C}$. ${ }^{75}$ Accurate mass balances for $\mathrm{N}$ (and P) during the cultivation stage would be of use in determining the magnitude of these impacts.

WATER REQUIREMENTS FOR MICROALGAL CULTIVATION

Microalgae cultivation requires large volumes of water, which should be considered in sustainability assessments of microalgae. As described by Guieysse et al., there is a difference between water demand (WD) and water footprint (WF). ${ }^{81}$ WD includes the water consumed by the process whereas WF always includes indirect water requirements and makes a difference between different types of water (green, blue, and grey). Most studies about microalgae concerns WD. To calculate the WD of a microalgal process, one must consider the volume of the system, the water lost in the biomass during harvesting, the proportion of process water that is reusable, loss due to leaks, and in the case of ORP systems, evaporation (Fig. 1). Different approaches to estimating the water requirements lead to a relatively large variation in the total WD of processes in different studies. Handler et al. reviewed the water usage for several LCAs published between 2002 and 2011 and found that of the ones that considered it, the values ranged from $0.001-0.11 \mathrm{~m}^{3} / \mathrm{kg} \mathrm{DW}$, depending on process configuration. ${ }^{67}$ They further found that additional water use for fertilizer production increased the water requirement by $0.002-0.013 \mathrm{~m}^{3} / \mathrm{kg}$ DW produced and energy production added an additional $0.003-0.070 \mathrm{~m}^{3} / \mathrm{kg}$ DW produced. ${ }^{67}$ These

\begin{tabular}{|c|c|c|}
\hline $\begin{array}{c}\text { WATER } \\
\text { RECYCLING (\%) }\end{array}$ & $\begin{array}{c}\text { WATER FOOTPRINT } \\
\left(\mathrm{M}^{3} / \mathrm{KG} \text { DW }\right)\end{array}$ & REFERENCE \\
\hline 100 & 0.24 & 43 \\
\hline 100 & 9.05 & $38^{a}$ \\
\hline 99 & 0.11 & 82 \\
\hline 99 & $0.035-0.054$ & $83^{b}$ \\
\hline 99 & 0.01 & $84^{c}$ \\
\hline 95 & 0.33 & 85 \\
\hline 90 & 0.51 & $81^{d}$ \\
\hline 90 & $0.388-0.726$ & $6^{e}$ \\
\hline 84 & 0.005 & $47^{f}$ \\
\hline 80 & $0.56-1.08$ & $42^{9}$ \\
\hline 75 & 0.91 & $81^{\mathrm{d}}$ \\
\hline 50 & 1.55 & $81^{d}$ \\
\hline 0 & 1.01 & 82 \\
\hline 0 & 0.511 & $47^{f}$ \\
\hline 0 & 1.08 & 15 \\
\hline
\end{tabular}

a Used corrected values calculated by Guieysse et al. and a higher heating value of $24 \mathrm{MJ} / \mathrm{kg} \mathrm{DW}^{81}$; ${ }^{\text {bC}}$ Calculated from biodiesel to DW by accounting for lipid content and a $90 \%$ lipid-to-biodiesel conversion efficiency. Range represents the effect of biomass lipid content (40-70\% DW); 'Recalculated from volume of water required to produce 1,000 t DW; 'Values are for a tropical location (Hawaii), calculated based on a higher heating value of $24.7 \mathrm{MJ} / \mathrm{kg} \mathrm{DW}$; ${ }^{\text {eRange represents values }}$ for different locations throughout the US; fRecalculated based on $3326 \mathrm{~kg}$ DW being required to produce $1 \mathrm{t}$ biodiesel. Also considered addition of water from

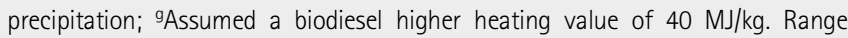
represents base-case to best-case scenarios.

factors should subsequently be considered in detailed LCA to properly ascertain the WD for biomass production.

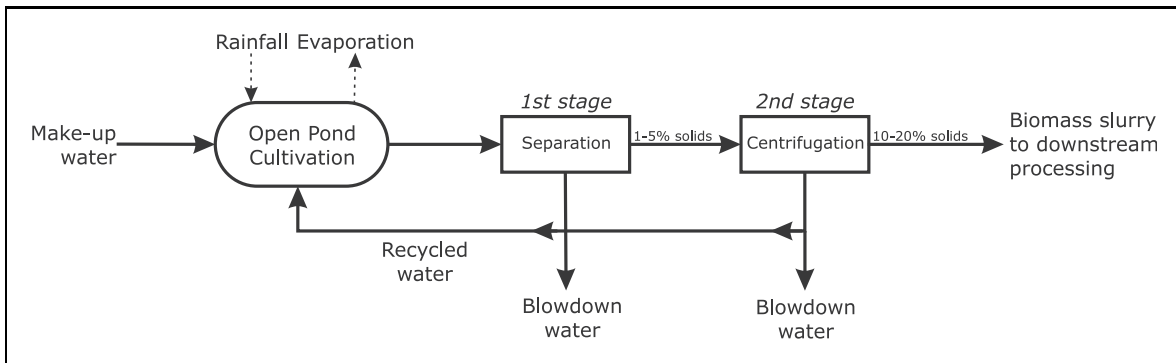

Fig. 1. Schematic of water flow in a microalgal cultivation scenario. Water is lost in the harvested biomass, but the majority is recyclable back to the cultivation system after initial separation (e.g., flocculation/dissolved air flotation) and final dewatering by centrifugation. Evaporation and rainfall will also contribute to water loss/gain in open systems, affecting the overall make-up water requirement.
Prospects for process water recycling. Recycling water from the harvested portion of the culture is key in reducing overall water usage. ${ }^{76,81}$ Studies assuming no recycling of process water for microalgal biodiesel production predict WDs of 1.75$3.36 \mathrm{~m}^{3} / \mathrm{L}$ biodiesel (Table 3), ${ }^{15,47,82}$ but this was decreased by $85-99 \%$ to $0.004-1.49 \mathrm{~m}^{3} /$ $\mathrm{L}$ biodiesel for scenarios recycling over $95 \%$ of the process water. ${ }^{48,76,82}$ It is not possible to recycle $100 \%$ of the process water following harvesting, as the methods typically used (i.e., filtration, centrifugation) can only concentrate suspensions to $10-20 \%$ solids. Subsequently, for every $1 \mathrm{~kg} \mathrm{DW}$ of algal 
biomass, there is likely to be at least $0.004-0.009 \mathrm{~m}^{3}$ of water still associated with it if drying is not undertaken.

Guieysse et al. predict water demand for ORPs with $75 \%$ water recycling of between $0.81-0.91 \mathrm{~m}^{3} / \mathrm{kg} \mathrm{DW}$, but as low as $0.51 \mathrm{~m}^{3} / \mathrm{kg}$ DW for scenarios with $90 \%$ recycling and as high as $1.55 \mathrm{~m}^{3} / \mathrm{kg}$ DW for $50 \%$ recycling. ${ }^{81}$ The amount lost in the harvested biomass and leak loss was kept constant in these calculations, so variations depend on differences in evaporation rate, which is approximately $10-36 \%$ of the total requirement. A number of other studies are summarized in Table 3.

Finally, reuse of the process water prevents the loss of residual nutrients in the media, and thereby possible further water treatment steps may be avoided. However, the recycling of water must be carefully considered, as it could lead to the buildup of inhibitory compounds ${ }^{86}$ or grazers and competing microorganisms after several rounds of reuse,${ }^{87}$ which together could lead to decreased culture productivity and culture crashes. There is now a growing body of literature examining the process of water recycling, with some studies finding no difference, a decrease, and even an improvement in growth rate with the reuse of process water. These results appear to be influenced by both species-specific effects and the method of harvesting employed.

Early studies examining Nannochloropsis sp. production found that this species demonstrated significantly lower volumetric biomass productivities following recycling of centrifuged culture media, which was mainly attributed to an increase in residual cell material causing an increase in cell aggregation and bacterial numbers. ${ }^{88}$ More recently, González-López et al. found that cultures of Nannochloropsis gaditana grew with a comparable rate on recycled process water following biomass harvesting via centrifugation, which was treated with either filtration or ozonation, as on fresh media. ${ }^{89}$ These results highlight the requirement for additional levels of treatment beside centrifugation to remove bacteria and cell debris prior to reuse of water in algal cultivation. Cross-flow membrane microfiltration may be one relatively costeffective solution for such a process. ${ }^{90}$

Flocculation could be used to increase the biomass concentration of approximately 1-7\% solids before further dewatering by more energy-intensive centrifugation or filtration. ${ }^{53}$ Different results have been seen for cultures grown on recycled water following flocculation. In particular, results with the common chemical flocculant alum showed both reduced biomass productivity ${ }^{91}$ and unchanged productivities, ${ }^{92}$ suggesting that the used concentration of this flocculant may be critical. Recently, the growth of Tetraselmis sp. was tested in both 'clean water' and recycled media under semi-continuous operation over 5 months. ${ }^{93}$ The recycled water after harvest by electro-flocculation was found to not significantly affect the growth of this species, despite an increase in salinity from 5.5 to $12 \%$, thereby considerably reducing the freshwater demand of production. ${ }^{93}$ The difference in growth rates may be due to the ability of some production systems to maintain low levels of bacteria or contaminating organisms in the media during the initial cultivation and the effectiveness of different harvesting techniques in the removal of such organisms. It also appears that some specific effects exist with the use of some species, such as the accumulation of cell debris during cell division in the case of Nannochloropsis sp. ${ }^{88}$ and dissolved organic compounds in cultures of Scenedesmus. ${ }^{86}$
A recent report from the company Sapphire Energy Inc. (San Diego) suggests that more than $97 \%$ of their process water is recycled at their pilot facility, ${ }^{94}$ and it is mainly coming from the primary dewatering step using dissolved air flotation of algal biomass (4-7\% solids). The rest of the water removed during secondary dewatering via centrifugation is sent to evaporation ponds. They have maintained this continuous, stable operation for over two years, and state that their water requirements are significantly lower than predicted by Guieysse et al. ${ }^{81}$ So there appears to be some success stories, but many studies only test one cycle of reuse, whereas it would be expected that the water would be reused many dozens of times during long production cycles, and the water will come from different processes at different stages of dewatering. The reuse of water should be considered on a case-by-case manner for different species, cultivation systems, and harvesting methods to conclusively determine the feasibility of reusing a high proportion of process water in large-scale systems.

Water evaporation in cultivation systems. Evaporation is an important issue for ORP systems. The rate of evaporation is likely to be highly variable and location-specific depending on climatic factors such as temperature (water and air), relative humidity, and wind velocity, but also reactor design and operation. Evaporation and process water loss together accounted for between $50-70 \%$ of water usage depending on location, according to Zaimes and Khanna. ${ }^{6}$

Evaporation can cause additional problems in cultivations utilizing marine species, where increases in the concentration of inorganic salts may negatively affect growth due to osmotic or ion stress. Selection of marine strains with a wide tolerance to changes in salinity may subsequently be critical for cultivation using seawater in ORPs in locations with expected high rates of evaporation. ${ }^{93}$ Replacing evaporated water with water of low salinity may also be necessary to maintain suitable growth conditions. Indeed, a recently isolated halo-tolerant Tetraselmis strain was grown continuously in ORPs where the media salinity increased from $5.5 \%$ to $12.0 \% \mathrm{w} / \mathrm{v} \mathrm{NaCl}$ due to evaporation (average $=0.02 \mathrm{~m}^{3} / \mathrm{m}^{2} / \mathrm{d}$ during summer in Western Australia), with no significant effect on growth. ${ }^{93}$ Venteris et al. also found that production scenarios utilizing species with flexible salinity tolerances will have a greater chance of finding a favorable location with regards to utility availability and maintaining consistent biomass productivities. ${ }^{23}$ They also conclude that there may be a trade-off regarding the siting of potential production facilities with regards to the ideal climatic conditions affecting growth rate and evaporation, and the proximity to an adequate water source. $^{23}$

Accurate prediction of evaporation rates is hence critical, not only in determining the water demand of the process, but also for informing the selection of appropriate production sites. Evaporation has typically been calculated using forms of panevaporation, lake-evaporation, or Penman models, which all require measurement of climatic conditions and were developed to estimate water evaporation from shallow water bodies. ${ }^{95}$ Panand lake-evaporation models have subsequently been used in a number of LCA studies, but could lead to underestimation of evaporation for the pond systems they examined. $6,12,38,76,85$ 
Béchet et al. further refined evaporation models for ORPs by more accurately predicting temperature changes. ${ }^{96}$ However, none of these approaches have been confirmed with empirical data for ORPs, and Guieysse et al. found that these models, applied to locations in different climates, resulted in a relative error of $17-25 \%$ for most locations, but was as high as $44 \%$ in the tropical location (Hawaii), due to differences in the way that the models dealt with air emissivity in such humid locations. ${ }^{81}$

Subsequently, based on average meteorological data, the calculations of Guieysse et al. predicted a maximum evaporation rate of $2.27 \mathrm{~m}^{3} / \mathrm{m}^{2} / \mathrm{y}$ in arid climates (Arizona), ${ }^{81}$ which is similar to the reported rate of evaporation of $2.03 \mathrm{~m}^{3} / \mathrm{m}^{2} / \mathrm{yr}$ for large-scale trials run in raceways $(\sim 39$ ha) by Sapphire Energy in a similar climate in New Mexico. ${ }^{94}$ The rates of evaporation from open ponds in tropical $\left(0.48 \mathrm{~m}^{3} / \mathrm{m}^{2} / \mathrm{y}\right.$; Hawaii), temperate $\left(0.74 \mathrm{~m}^{3} / \mathrm{m}^{2} / \mathrm{y}\right.$; Hamilton, New Zealand), subtropical $\left(1.15 \mathrm{~m}^{3} / \mathrm{m}^{2} / \mathrm{y}\right.$; Florida), and Mediterranean $\left(1.32 \mathrm{~m}^{3} /\right.$ $\mathrm{m}^{2} / \mathrm{y}$; California) climates have also been calculated. ${ }^{81}$ Similar values are predicted by Zaimes and Khanna using a modified Penman model for different US locations, ${ }^{6}$ but when the rate of precipitation is considered, Arizona, Southern California, and part of Texas were found to still require considerable make-up water due to evaporation.

To more accurately predict evaporation from algal ponds, highly detailed temporal meteorological data is required for specific locations, which should be used alongside appropriate modeling approaches. Ideally, these should in turn be validated at these locations with long-term empirical data. This suggests that input from companies such as Sapphire Energy, Cyanotech Corporation (Kailua-Kona, HI), and Cellana (San Diego, CA), or multipartner and location collaborations such as the Arizona Testbed Public-Private Partnership Plant (Mesa, AZ) would greatly improve the accuracy of modeling approaches.

\section{CARBON REQUIREMENT FOR BIOMASS PRODUCTION}

Inorganic carbon is essential for photoautotrophic growth and needs to be supplied to cultures (most typically as $\mathrm{CO}_{2}$ ) to achieve high growth rates and biomass production. The literature is rich in examples explaining the requirements of $\mathrm{C}$ for biomass production ${ }^{97,98}$ and is generally well covered in system assessments due to the availability of empirical data, both from lab-scale and, more recently, pilot-scale studies, for simulated and actual waste gases. For $\mathrm{CO}_{2}$ supply, an obvious source will be flue gases from different industrial processes, e.g., combustion and processing. Even during the early 1990's, research groups were investigating the abatement of $\mathrm{CO}_{2}$ from flue gases using microalgal cultivation, ${ }^{99-101}$ and the topic has received considerable attention ever since.

From a biological point of view, microalgal biomass is reported to contain $40-60 \% \mathrm{DW}$ as $\mathrm{C} ;{ }^{.56}$ this results in a $\mathrm{CO}_{2}$ fixation of $1.5-2.2 \mathrm{~kg} \mathrm{CO}_{2} / \mathrm{kg} \mathrm{DW}$. Based on recently published productivity data from ORPs and flat-panel systems, average biomass productivities could be 6.6 and $19.0 \mathrm{~g} \mathrm{DW} / \mathrm{m}^{2} / \mathrm{d}(\mathrm{Ta}$ ble 1$),{ }^{26}$ respectively, which corresponds to a fixation of approximately 42.3 and $121.8 \mathrm{t} \mathrm{CO}_{2} / \mathrm{ha} / \mathrm{y}$ in biomass, respectively (assuming a $50 \% \mathrm{DW} \mathrm{C}$ content). A recent study from a large ORP trial in Korea examined the fixation of $\mathrm{CO}_{2}$ under ambient environmental conditions and found that $\mathrm{CO}_{2}$ fixation was 64.4-142 t CO$_{2} / \mathrm{ha} / \mathrm{y}$, depending upon the daily incidence irradiance and temperature. ${ }^{102} \mathrm{~A}$ readily available $\mathrm{CO}_{2}$ supply is hence critical for large-scale microalgal cultivation.

$\mathrm{CO}_{2}$ is highly soluble in water, but when bubbled into a culture, depending on the reactor geometries, mixing, bubble size, temperature, $\mathrm{pH}$ and, biomass concentration (among many other factors), a certain quantity of $\mathrm{CO}_{2}$ will not dissolve and is effectively lost in the off-gas. The percentage that is not lost is sometimes referred to as the $\mathrm{CO}_{2}$-use efficiency. Collet et al. found that only $44 \%$ of LCA accounted for these losses, with those that did having an average $\mathrm{CO}_{2}$-use efficiency of $82 \%{ }^{20}$ de Godos et al. recently examined the amount of $\mathrm{CO}_{2}$ released from an ORP at different liquid velocities in the absence of algal cells. ${ }^{33}$ They found that once the culture media was saturated the percentage of $\mathrm{CO}_{2}$ dissolved into the culture media was approximately $87 \%$. However, when live cells were added, $90 \%$ dissolved into the media and $66 \%$ of the total $\mathrm{C}$ added to the media was fixed in the biomass, with the rest remaining as dissolved inorganic $\mathrm{C}$ (DIC) in the media. ${ }^{33}$ These results serve to highlight the importance of optimizing $\mathrm{CO}_{2}$ addition (flow rate, $\mathrm{pH}$ ) to minimize $\mathrm{CO}_{2}$ loss, while maintaining high growth rates. $\mathrm{CO}_{2}$-fixation efficiency is considered to be significantly higher in closed systems, with many LCA not considering it or assuming a $0 \%$ loss to the environment. ${ }^{47,78}$ The $\mathrm{CO}_{2}$-uptake efficiency is critical in determining the overall GHG-emission avoidance associated with using flue gas; for an inefficient system, large quantities of gas are needed that will require liquefaction/transportation, which are inherently energy-intensive processes. ${ }^{103}$ Additionally, if large quantities of DIC are lost in the harvested culture media ( $>24 \%$ of $\mathrm{C}$ for de Godos et al.), ${ }^{33}$ this places added importance on the recycling of culture media to reduce the need for additional $\mathrm{CO}_{2}$. It is unclear whether fixation of $\mathrm{CO}_{2}$ as DIC in discharged waters would be acceptable for contributing to hypothetical $\mathrm{CO}_{2}$ fixation credits generated from microalgal cultivation. ${ }^{98}$ Calculations of $\mathrm{CO}_{2}$ requirements should subsequently consider this when calculating the rate of supply to meet culture requirements.

Flue gas composition and considerations for use. Flue gases from the combustion of fossil resources contain $\mathrm{CO}_{2}$ contents of $8-20 \%(\mathrm{v} / \mathrm{v})$, with those derived from natural gas having a lower $\mathrm{CO}_{2}$ content than those from coal, which can have contents $>15 \%{ }^{98,104,105}$ The gases from the production of ammonia fertilizer, hydrogen, lime, or fermentation exhaust gases can typically contain $>90 \% \mathrm{CO}_{2}$ content. ${ }^{104,106}$

The delivery of $\mathrm{CO}_{2}$ to cultures needs to be such that the media DIC concentration is non-limiting for microalgal growth, but not added at a concentration that would significantly acidify the cultivation media and negatively affect the growth. Tolerance to high $\mathrm{CO}_{2}$ concentrations in gases is dependent on the loading rate (both $\mathrm{CO}_{2}$ content and gas flow rate) and cell density, ${ }^{98,107}$ culture $\mathrm{pH},{ }^{105}$ cultivation conditions such as light and nutrient regime, ${ }^{107}$ and species-specific traits. ${ }^{98,108}$

Untreated flue gases also contain significant quantities of sulphurous and nitrogenous oxides $\left(\mathrm{SO}_{2}\right.$ and $\left.\mathrm{NO}_{\mathrm{x}}\right)$, carbon monoxide, as well as metals and particulates-particularly if from coal or oil combustion. ${ }^{98,104,109}$ These compounds have 
been shown to have numerous environmental and human health impacts, and their removal post-combustion is heavily regulated. ${ }^{110}$ Both $\mathrm{SO}_{2}$ and $\mathrm{NO}_{\mathrm{x}}$ have the potential to acidify the growth media. $\mathrm{SO}_{2}$ forms sulphite $\left(\mathrm{SO}_{3}{ }^{2-},>\mathrm{pH} 6\right)$ or bisulphite $\left(\mathrm{HSO}_{3}{ }^{-}, \mathrm{pH} 2-6\right)$, which have been found to be toxic to a number of green algae. ${ }^{111}$ Nitric oxide (NO) and nitrogen dioxide $\left(\mathrm{NO}_{2}\right)$ are the major $\mathrm{NO}_{\mathrm{x}}$ compounds found in flue gases. ${ }^{98} \mathrm{NO}_{2}$ is more soluble, although some algae species were reportedly able to utilize NO directly. ${ }^{112}$ Desulphurization and denitrification processes can remove up to $90 \%$ of these oxides from gases $(<\mathrm{ppt})$, and $90 \%$ of dust and heavy metal contaminants can also be removed. ${ }^{110}$

Several studies have examined the ability of microalgae to grow on gases containing varying concentrations of $\mathrm{CO}_{2}$ in combination with ppm concentrations of $\mathrm{NO}_{\mathrm{x}}$ and $\mathrm{SO}_{\mathrm{x}}$, as well as actual flue gases; results are summarised in several reviews. $^{97,98}$ Of particular note is the work of Douskova et al., which found that Chlorella vulgaris was able to grow on cooled flue gas containing $10-13 \% \mathrm{CO}_{2}$ (gas flow rate $=1.2 \mathrm{~L} / \mathrm{L} / \mathrm{min} \mathrm{v} /$ $\mathrm{v})$, and that the level of $\mathrm{SO}_{2}(1.56 \mathrm{ppm}), \mathrm{NO}_{\mathrm{x}}(88-136 \mathrm{ppm})$, and other contaminants (metals, polycyclic aromatic, polychlorinated biphenyls) did not impair growth. ${ }^{109}$ However, the resulting biomass had a mercury concentration greater than permitted by EU food product legislation $(>1 \mathrm{mg} / \mathrm{kg})$, despite the gas having undergone post-combustion treatment to remove $\mathrm{NO}_{\mathrm{x}}, \mathrm{SO}_{\mathrm{x}}$, and metals. Further treatment of the flue gas by passing over activated carbon absorbed the remaining mercury and resulted in biomass meeting the requirements.

Considering the bioaccumulation of potentially toxic compounds is imperative if the production of food-grade products is intended; however as removal processes for many harmful contaminants are now mandated by government legislation in many industrial economies, many flue gas sources may subsequently be suitable for growth of microalgae. A more detailed review of flue gases, $\mathrm{NO}_{\mathrm{x}}$ and $\mathrm{SO}_{\mathrm{x}}$ species formation, remediation, and their effects on microalgal growth and physiology is provided by Van Den Hende et al. ${ }^{98}$

Considering $\mathrm{CO}_{2}$ supply in LCA and TEA. The availability of adequate flue gases for supply of $\mathrm{CO}_{2}$ has been reported to be a major factor constraining the geographic placement of large-scale microalgal production facilities in the US $\mathrm{US}^{22,42}$-more so than land, water, and nutrient availability. ${ }^{24}$ Most LCAs consider the $\mathrm{CO}_{2}$ requirements of their production scenarios to be met from flue-gas sources, $, 9,42,48,80$ with a few comparing this process against the use of liquefied $\mathrm{CO}_{2}$. 6,7,14,40,113

Commercially produced liquid $\mathrm{CO}_{2}$ is assumed to be generated using amine stripping of concentrated $\mathrm{CO}_{2}$ sources, such as from fermentation facilities or ammonia production from natural gas. ${ }^{104}$ The total energy demand for the production of liquefied $\mathrm{CO}_{2}$ is difficult to determine for commercial operations, but precombustion capture from ammonia production facilities is calculated to be 400-500 MJ/tonne (t) $\mathrm{CO}_{2},{ }^{114}$ and $\mathrm{CO}_{2}$ liquefaction by conventional processes accounts for an additional $359 \mathrm{MJ} / \mathrm{t}$ $\mathrm{CO}_{2}{ }^{115}$ A price of $\$ 40 / \mathrm{t}$ is often used for liquefied $\mathrm{CO}_{2}$ delivered on site. ${ }^{7,40}$ The additional energy requirement of storing liquefied $\mathrm{CO}_{2}$ on site is also rarely considered. Campbell et al. suggest that onsite storage and cooling of liquefied $\mathrm{CO}_{2}$ would require approximately $5.4 \mathrm{MJ} / \mathrm{t} \mathrm{CO}$ (assumed liquid state of $\sim 1 \mathrm{t} / \mathrm{m}^{3}$ at $350 \mathrm{psi}$ ). ${ }^{40} \mathrm{Un}$ fortunately, several older LCA only consider the energy required for delivery and distribution of $\mathrm{CO}_{2}$, and not the upstream burdens associated with liquefied $\mathrm{CO}_{2}$ production or its storage on site. ${ }^{46,59,78}$ Other studies have shown significant lifecycle impacts for these processes., ${ }^{7,40,42}$ Some studies have allocated burdens associated with the use of commercial liquefied $\mathrm{CO}_{2}$ equally between the $\mathrm{CO}_{2}$ producer and the algae producer, as the coproducts of ammonia production are equal parts saleable hydrogen and $\mathrm{CO}_{2}$ production, decreasing the energy and environmental impacts of $\mathrm{CO}_{2}$ supply for microalgal cultivation. ${ }^{38,78,113}$

The $\mathrm{CO}_{2}$ requirements for a cultivation facility (ORPs and PBRs) based in Arizona ${ }^{26}$ were considered, and the energy and costs of supplying this site calculated (Table 4). The energy requirements of $\mathrm{CO}_{2}$ supply represent 8.0 and $6.6 \%$ of the energy contained in the produced biomass for ORP and PBRs, respectively (assuming higher heating value of $24 \mathrm{MJ} / \mathrm{kg} \mathrm{DW}$ ). These values highlight how critical the use of $\mathrm{CO}_{2}$ from waste gas streams will be for large-scale cultivation; however, this will only be effective if production facilities are sited close to the $\mathrm{CO}_{2}$ source to minimize the cost of transport. ${ }^{22,40,106}$
Table 4. The $\mathrm{CO}_{2}$ Requirements of Two Biomass Production Scenarios Based on the Average Areal Biomass Productivity of ORPs and Flat-Panel

PBRs Operated in Arizona ${ }^{26}$ and the Subsequent Energy Requirements and Cost of Using Liquefied $\mathrm{CO}_{2}$ to Meet the Cultivation Requirements

\begin{tabular}{l|c|c|c|c} 
& \multicolumn{2}{|c|}{ ORP } & 66.5 & \\
\hline $\begin{array}{l}\text { Biomass production } \\
\text { (t DW/ha/y) }\end{array}$ & 23.1 & & 100 & \\
\hline $\mathrm{CO}_{2}$ fixation (\%) & 82 & & 121.79 & \\
\hline $\begin{array}{l}\mathrm{CO}_{2} \text { requirement } \\
(\mathrm{t} / \mathrm{ha} / \mathrm{y})^{\mathrm{a}}\end{array}$ & 51.6 & & Per area (/ha/y) & Per biomass (/t DW) \\
\hline & Per area (/ha/y) & Per biomass (/t DW) & 1242 & 926 \\
\hline $\begin{array}{l}\text { Energy requirement } \\
\text { for liquefied } \mathrm{CO}_{2}(\mathrm{GJ})^{\mathrm{b}}\end{array}$ & 527 & 1129 & 5029 & 75.6 \\
\hline $\begin{array}{l}\text { Cost of liquefied } \\
\mathrm{CO}_{2}(\$)^{\mathrm{c}}\end{array}$ & 2131 & 92.2 & & \\
\hline
\end{tabular}

The biomass $\mathrm{C}$ content is assumed to be $50 \% \mathrm{DW}$; ${ }^{\text {Th }}$ The energy required for liquefied gas production were based on LCA data from Ecolnvent, ${ }^{116}$ and the energy of storage calculated to be $5.36 \mathrm{MJ} / \mathrm{t} \mathrm{CO}{ }^{4}{ }^{40}$ These calculations do not include the energy required for transport. 'The cost of $\mathrm{CO}_{2}$ is based on a $\$ 40 / \mathrm{CO}_{2}$, and the price of industrial electricity was $\$ 0.24 / \mathrm{MJ}$, which is the average US price for December $2015 .{ }^{117}$ This does not include the cost of transport. 


\section{MAYERS ET AL.}

The benefits of utilizing flue gases over liquefied $\mathrm{CO}_{2}$ have also been highlighted in several LCA and TEA, but results show sensitivity to the concentration of $\mathrm{CO}_{2}$ in the gas. ${ }^{6,7,14,40,103}$ The lower the $\mathrm{CO}_{2}$ percentage, the greater a volume of gas that requires transportation which may subsequently limit the distance a gas can be transported before any potential benefits are eroded. ${ }^{22,103}$ If the $\mathrm{CO}_{2}$ concentration of the flue gas is $15 \%$, approximately 6-times the volume of gas would require transportation compared flue gas containing $>95 \% \mathrm{CO}_{2}$ from an ammonia plant, for example - resulting in 53 vs. $7.9 \mathrm{MJ} / \mathrm{t}$ $\mathrm{CO}_{2}$ for each scenario for plants located $<2.5 \mathrm{~km}$ away. ${ }^{40}$ Based on these values, it is estimated that the use of $\mathrm{CO}_{2}$ in flue gases or from ammonia production instead of liquefied $\mathrm{CO}_{2}$ could reduce operational energy usage by as much as 94 and $99 \%$, respectively, corresponding to cost savings of 69 and $95 \%$, respectively. These calculations assume any postcombustion treatment of the gases would be included in the operators costs and energy expenditure. These values are quite ambitious, as opportunities for siting large cultivation facilities within $2.5 \mathrm{~km}$ of $\mathrm{CO}_{2}$ sources are very few. However, Coleman et al. still predict the cost will be lower than liqueified $\mathrm{CO}_{2}$ if transported less than $25 \mathrm{~km}$ from a concentrated $\mathrm{CO}_{2}$ producer $\left(>95 \% \mathrm{CO}_{2}, \$ 11.8 / \mathrm{t}\right)$ and $10 \mathrm{~km}$ for flue gases $\left(5 \% \mathrm{CO}_{2},<\$ 25 / \mathrm{t}\right) .{ }^{106}$

A 30-MW steam boiler combusting natural gas (92\% efficiency) produces enough energy to provide power to approximately 20 US households ( 67 in the EU) and emits $26,680 \mathrm{t} \mathrm{CO}_{2} /$ $\mathrm{yr}\left(12 \% \mathrm{CO}_{2}\right)$ on average (data from own source). The ORP or PBR systems described above ${ }^{26}$ covering 1 ha would fix between $0.13-0.19 \%$ and $0.37-0.55 \%$ (40-60\% DW C content), respectively, of this plant's annual $\mathrm{CO}_{2}$ emissions. This is a relatively small percentage of the emissions for such a boiler, which is also a relatively small capacity boiler compared to those at many large-scale power plants $(>1,000 \mathrm{MW})$. The abatement of such small quantities of $\mathrm{CO}_{2}$ would only marginally benefit the emitter, unless the microalgal process is scaledup dramatically (and $\mathrm{CO}_{2}$ is paid for), in which case land availability becomes a critical issue. ${ }^{22,24}$ The benefits to the biomass producer of procuring a cheap and more sustainable $\mathrm{CO}_{2}$ source are evident, in particular for bulk products such as feed and fuel, and is one of the key selling points of many microalgal technologies. Nevertheless, further work is required at larger scales with gases of different composition and quality (after processing) to understand their effect on biomass production to identify technology gaps, as well as give more accurate predictions on the cost and energy requirements of installation and operation. This would allow for more accurate calculation of the benefits of integration on both a life cycle and techno-economic basis.

\section{OPPORTUNITIES FOR HEAT INTEGRATION}

Heat integration of the downstream processing stages of microalgal biorefineries, identified using, for example, pinch analysis, can be another way to reduce the primary energy demand of the overall process. ${ }^{118}$ Depending on climatic conditions, heating or cooling of the culture broth may be required to maintain the temperature in the range that allows for maximum growth rates $\left(20-30^{\circ} \mathrm{C}\right) .^{36,96}$ Downstream processes may also require additional heat; this could be for drying microalgal biomass post-harvest, improving product extraction efficiency, evaporation and recovery of solvents post biomass extraction, or processing biomass via thermochemical conversion routes. The amount and quality (temperature) of heat required for each of these processes will be very different. For example, maintaining pond temperatures a few degrees above ambient may require hot water of only approximately $60^{\circ} \mathrm{C},{ }^{119}$ drying of biomass may require heat above $80^{\circ} \mathrm{C}$, and thermochemical techniques typically operate above $200^{\circ} \mathrm{C}$. The supply of heat from industrial sources, either as hot gases, such as flue gases (typically $>130^{\circ} \mathrm{C}$ ), or process cooling water could be leveraged for use in one of these heat-requiring processes. Another study using pinch analysis indicated a reduction of cooling and heating utilities by $11-13 \%$ for a process where biodiesel was produced from microalgae oil in two sequential esterification/transesterification reactions. ${ }^{120}$

Although the definition of industrial excess heat and similar concepts (e.g., waste heat, surplus heat, secondary heat) varies widely, ${ }^{121,122}$ it is, inarguably, a large resource that could be used to increase the energy efficiency of an industriallyintegrated microalgal biorefinery. Industrial excess heat, not only from power plants, but also from, for example, oil and petrochemical refineries or pulp and paper mills, is being used today, mainly for district heating purposes, but there is still a large potential for increased heat recovery. ${ }^{121,122}$ Use of industrial waste heat is currently thought to be limited by a knowledge gap, not just in the production of microalgae, but across a range of industries. ${ }^{123}$

Regional estimations of excess heat potentials can be obtained using top-down or bottom-up approaches. ${ }^{124}$ However, the potential for the supply of heat from industrial sources to a microalgal process is, ultimately, highly site-specific and depends on the amount, temperature profile, and short-term and seasonal variations of the heat available. It also depends on the potential alternative uses of heat-for example, internal heat recovery for district heating, as a heat source in refrigeration plants, or for low-temperature electricity generation. ${ }^{125}$ An issue to consider is that the availability of industrial excess heat tends to be the highest when the demand from the microalgal process is the lowest (typically on a warm summer day).

Culture temperature. For most microalgae there is a relatively small temperature range in which they obtain their maximum growth rates $\left(20-30^{\circ} \mathrm{C}\right){ }^{96,126,127}$ At high culture temperatures, there is decreased protein functionality and photosynthetic inhibition, ${ }^{127}$ eventually leading to loss of viability. At suboptimal temperatures, cells can become light saturated at lower irradiances. ${ }^{127}$ Seasonal variations as well as daily fluctuations in temperature are a significant determining factor on microalgal productivity for cultivation systems sited outdoors. ${ }^{96}$ At higher latitudes, outdoor production systems with no system for maintaining temperature above ambient are highly unlikely to be productive enough to warrant operation during winter months (also due to low irradiances).

A case study of an algae cultivation and biofuel production process integrated with an industrial cluster consisting of two oil refineries and a waste water treatment plant in West Sweden is 
one of the few studies considering geographically explicit and site-specific conditions for industrial heat supply to a microalgal biorefinery. ${ }^{16}$ Depending on growth-rate assumptions, estimates show that excess heat from the refineries (175 MW) can make a significant contribution to the heating demand of the ORP (112372 MW in February), but is still not sufficient to maintain acceptable growth rates during winter at these climate conditions. Nevertheless, the study points to the importance of including utilization of industrial excess heat when performing LCA studies of similar biorefinery concepts. Laamanen et al. also demonstrate the potential of using industrial excess heatin their case from a nickel smelter-to maintain year-round cultivation of microalgae at different geographical locations. ${ }^{128}$

The problem of excessive ambient temperatures has also been highlighted using a model to predict culture temperature fluctuations and heating and cooling demands for a PBR of different geometries and location. ${ }^{96,126}$ They found that for PBRs located in California, culture temperatures would regularly surpass $40^{\circ} \mathrm{C}$ in summer months; this study predicted that, maintaining temperatures at or below 25 and $30^{\circ} \mathrm{C}$ would require the removal of 18,000 and $5,500 \mathrm{GJ} / \mathrm{ha} / \mathrm{y}$ of heat energy, respectively. ${ }^{126}$ Considering that flat-panel PBR systems located in Arizona are predicted to have an annual biomass production of $\sim 65 \mathrm{t} / \mathrm{ha} / \mathrm{y},{ }^{26}$ with an estimated energy yield of $\sim 1600 \mathrm{GJ} / \mathrm{ha} / \mathrm{y}$, this result indicates that the required cooling could make the concept at this location entirely unfeasible if energy feedstock generation is the aim. These results show the serious implications of attempting to control temperature of outdoor systems for the production of bioenergy feedstocks and bulk products. Innovative pond designs that are responsive to climatic conditions have recently been investigated and patented with the aim of maintaining relatively constant pond temperatures, even in arid locations, such as Arizona, ${ }^{129}$ which may help reduce costs, compared to use of cooling systems. ${ }^{31,94,130}$

An alternative strategy that may improve annual production is to operate a system of crop rotation with different strains that can tolerate different temperatures cultivated in the corresponding seasons. Hueseman et al. recently presented results suggesting that an $8-25 \%$ increase in biomass productivity (depending upon location and pond depth) can be achieved by rotating between two strains relative to using just one. ${ }^{130}$ This strategy may also aid in the management of contaminants and pathogens, as is done in traditional arable agriculture. ${ }^{131}$ Identifying strains with optimal growth rates close to the extremes of temperature experienced in a particular location may be key in achieving economically feasible year round production.

Integration downstream. Heat integration of the downstream processing stages of microalgal biorefineries is another way to reduce the primary energy demand of the overall process. A good example of this, presented by Song et al., identifies heat in- tegration opportunities by which waste heat associated with dryer exhaust gas and the top stream of a distillation column is recompressed to provide heat for drying and oil extraction, thereby reducing energy demand of the process by more than $50 \%{ }^{132}$

Perhaps the easiest way to envisage the use of heat recovery in downstream processing operations is the drying of biomass (Fig. 2). Biomass may need to be dried to preserve composition, or to facilitate other downstream processes, requiring a very low moisture content, such as pyrolysis or conventional gasification. ${ }^{15}$ A number of different drying options may be suited for the drying of algae (in terms of preservation and product characteristics), but should also be selected for based on the operational requirements (scale and capacity), capital cost, and operational energy demand. Freeze-drying, spraydrying, and roller-dryers have all seen use for drying of different algal species. ${ }^{15,53,133}$ Most LCAs include a drying step in bioenergy production scenarios to evaluate the use of natural gas-based dryers and find this process to be a critical energy demand for microalgal biorefineries., 5,54 Consequently, the importance of wet biomass processing techniques has been emphasized. ${ }^{54,79,134}$ Two recent studies have shown that the use of mild acids and moderate temperatures can aid in valorization of wet biomass via sequential fermentative ethanol production from biomass carbohydrates and residual lipid extraction. ${ }^{135,136}$ Water evaporation requires approximately 2.26 $\mathrm{MJ} / \mathrm{kg} \mathrm{H}_{2} \mathrm{O}$, but values quoted in systems analysis can be as much as $3.6 \mathrm{MJ} / \mathrm{kg} \mathrm{H}_{2} \mathrm{O}$, depending on the equipment employed. ${ }^{53,54,134}$ Combined with differences in the solids content before and after drying and the different equipment being used, results in the literature for the energy required to dry $1 \mathrm{~kg}$ of microalgal biomass were calculated to be 11.6-70.7 MJ/kg DW for conventional drying systems (Table 5), but lower for more advanced systems $(<5 \mathrm{MJ} / \mathrm{kg} \mathrm{DW})$. Ventura et al. evaluated calculations of thermal drying energy costs from other LCA $(0.24-0.40 \mathrm{MJ} / \mathrm{kg} \mathrm{DW}),{ }^{84}$ but were an order of magnitude lower than have been calculated here using the data in the

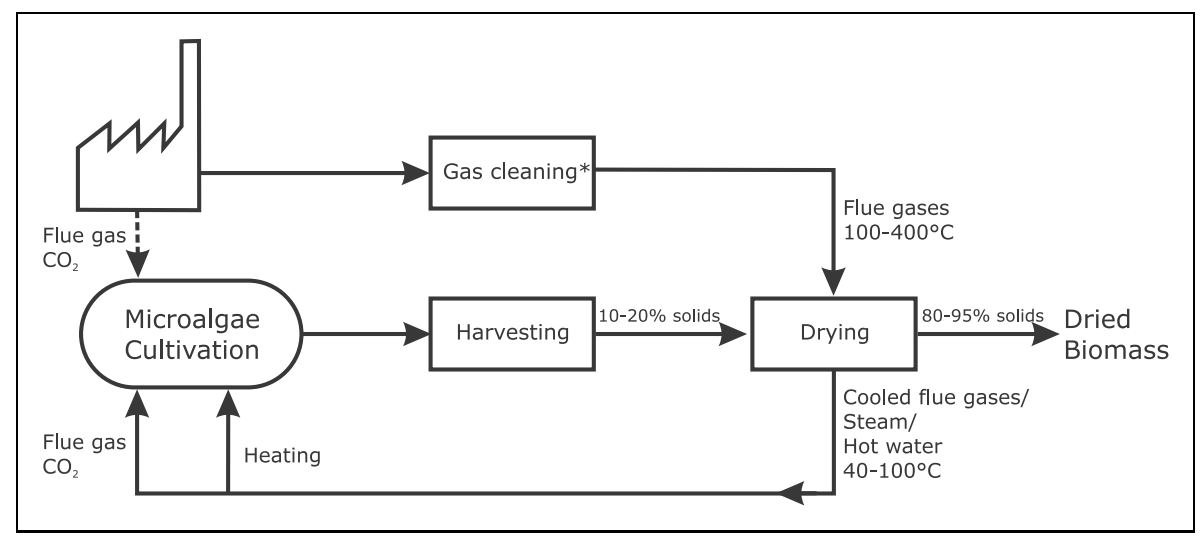

Fig. 2. Schematic of possible routes for integration with an industrial facility, using flue gases as a source of $\mathrm{CO}_{2}$ and heat. Flue gases are typically cleaned $\left(^{*}\right)$ to remove particulates, metals, and nitrogen and sulphur oxides. Depending on treatment methods required, flue gases will have different temperatures. Flue gases could be supplied directly to cultures as a $\mathrm{CO}_{2}$ source (dashed arrow), but is dependent on gas composition and will likely require cooling. Alternatively, hot gas streams can first be utilized for biomass drying and then used for heating of cultures and $\mathrm{CO}_{2}$ supply. 
Table 5. Predicted Energy Requirements for Drying Microalgae Biomass from the Literature

\begin{tabular}{c|c} 
& BIOMASS DRY \\
ENERGY & MATTER BEFORE
\end{tabular}

REQUIREMENT AND AFTER DRYING

$(\mathrm{MJ} / \mathrm{kg} \mathrm{DW})$ (\% DW)

WATER

REMOVED $\left(\mathrm{m}^{3} / \mathrm{kg} \mathrm{DW}\right)$

DRYING METHOD REFERENCE

\begin{tabular}{l|c|c|l|c}
\hline 0.12 & $? \rightarrow 90$ & - & Integrated steam rotary dryer & $138^{\mathrm{a}}$ \\
\hline 5.0 & $16 \rightarrow 30 \rightarrow 85$ & $2.92+2.16$ & Mech. + Delta dryerbc & 134 \\
\hline 7.76 & $24 \rightarrow 80$ & 2.92 & Rotary kiln dryer & 15 \\
\hline 11.2 & $16 \rightarrow 85$ & 5.07 & Delta dryer ${ }^{\mathrm{b}}$ & 134 \\
\hline 11.6 & $30 \rightarrow ?$ & - & NGD & $14^{\mathrm{d}}$ \\
\hline 12.0 & $20 \rightarrow 90$ & 3.89 & NGD & 7 \\
\hline 13.4 & $15 \rightarrow 96$ & 5.63 & Freeze-dryer & $133^{\mathrm{e}}$ \\
\hline 13.6 & $25 \rightarrow 90$ & 2.89 & NGD & $6^{\mathrm{f}}$ \\
\hline 14.6 & $?$ & - & $?$ & $42^{\mathrm{g}}$ \\
\hline 15.2 & $20 \rightarrow 90$ & 3.89 & Belt dryer & $43^{\mathrm{h}}$ \\
\hline 16.2 & $10.2 \rightarrow 89$ & 3.43 & NGD & $6^{\mathrm{f}}$ \\
\hline 31.6 & 8.68 & NGD & 9 \\
\hline
\end{tabular}

NGD, Natural Gas Dryer; Mech., Mechanical vacuum dryer.

${ }^{a}$ Based on a theoretical steam tube rotary dryer with two inline pre-heaters integrated with waste heat from flue gas; ${ }^{b} \mathrm{An}$ advanced and more efficient dryer estimated to require $2.3 \mathrm{MJ} / \mathrm{kg} \mathrm{H}_{2} \mathrm{O}$ evaporated ${ }^{139}$; ' $\mathrm{C}$ Combination of mechanical vacuum drying from 16 to $30 \%$ DW followed by Delta dryer; ${ }^{d}$ Calculated based on $3.87 \mathrm{~kg}$ DW required to produce $1 \mathrm{MJ}$ biodiesel. $1.12 \mathrm{MJ}$ heat reportedly required for drying of $1 \mathrm{MJ}$ biodiesel. Assumes 30\% DW solids after centrifuging; 'Empirical data: Freeze dryer had an energy consumption of $190 \mathrm{MJ} / \mathrm{d}$, and an ability to remove $80 \mathrm{~kg}$ $\mathrm{H}_{2} \mathrm{O} / \mathrm{d}$, resulted in $14.2 \mathrm{~kg}$ DW/d processed based on solid concentration before and after drying; ${ }^{\mathrm{f}} \mathrm{Calculated}$ based on data in the text, suggesting drying constitutes 73 and $87 \%$ of the produced energy for filter press (25\% DW) or centrifugation (22\% DW) scenarios, respectively. Lower heating value $=18.7 \mathrm{MJ} / \mathrm{kg} \mathrm{DW} ;{ }^{9}$ Assumed $40 \mathrm{MJ} / \mathrm{kg}$ biodiesel

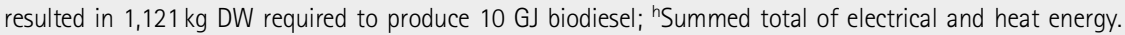

has been suggested as a solution for drying of algae, ${ }^{113}$ but might not be suitable for fine powders. Collet et al. calculated that a 500-MW, gas-fired power plant would produce $12 \mathrm{MJ} / \mathrm{d}$ of waste heat, ${ }^{37}$ which is 3,000-times greater than the energy required to dry the quantities of biomass predicted to be produced daily on a hectare basis $(65-300 \mathrm{t} / \mathrm{ha} / \mathrm{d})^{7,36}$ Rickman et al. also considered the use of waste heat in flue gas for the drying of biomass from $10 \% \mathrm{DW}$ to $85 \% \mathrm{DW}$ (98.8\% water removal). ${ }^{103}$ They estimate that flue gas $\left(150^{\circ} \mathrm{C}\right)$ from a 500 MW power plant would supply not only enough $\mathrm{CO}_{2}$ for the growth of microalgae over a 120-ha area, but also enough heat to dry the daily production of biomass for this area, even if drying efficiency was $50 \% .^{103}$

Aziz et al. modelled the use of a stateof-the-art steam tube rotary dryer (compressed steam flows counter-current through a central tube inside a rotary drum) in-line with 2 preheaters for drying of microalgal biomass using flue gases. ${ }^{138}$ The preheaters are directly fed with hot flue gas $\left(110^{\circ} \mathrm{C}\right)$, while steam $\left(90-130^{\circ} \mathrm{C}\right)$ generated from flue gases exiting a gasification process is fed to the rotary drum. The lowest input of energy per $\mathrm{kg}$ was found for a process drying the biomass to $90 \% \mathrm{DW}$, for which they calculated that the energy requirement could be decreased to $0.12 \mathrm{MJ} / \mathrm{kg} \mathrm{DW}$ using

original studies (5.0-15.2 MJ/kg DW; Table 5). Even low predictions of the energy requirement for drying make bioenergy feedstocks energetically unfavourable, while also contributing significantly to GHG emissions and fossil resource usage. , $43,54^{-1}$ This places the emphasis on developing more energy efficient dewatering techniques to remove as much extracellular moisture as possible before drying. ${ }^{54,134}$

Integration with an industrial plant that supplies excess heat for the drying of biomass may subsequently reduce the primary energy demand and GHG emissions of the microalgal processes, ${ }^{125}$ which may lead to economic gains over stand-alone processes. However, consideration must be given to the type of dryer that would be suitable for use with the waste heat. Those integrated with flue gas for wood biomass drying are typically in the form of conveyor belt dryers or drum dryers, where the flue gas can be directly passed over the material. ${ }^{137}$ Indirect drying via heat exchangers could be used for the transfer of heat from gases to liquids, which might be more flexible with regard to equipment and avoid direct exposure of the biomass and equipment to potentially corrosive or toxic gases. ${ }^{125}$

At fossil-fuel power plants, residual heat in flue gases is used to heat air in a conveyor dryer to improve the thermal efficiencies. This their system (Table 5). ${ }^{138}$ Furthermore, the exiting temperature of the flue gas from the preheaters was predicted to be $40-57^{\circ} \mathrm{C}$, which would be suitable for maintaining the temperature of the culture during cooler months via heat exchangers (Fig. 2).

Results from these and other studies also conclude that the level of heat integration has a significant effect on both the environmental performance $e^{9,17,18}$ and economics of microalgal processes. ${ }^{17}$ These results highlight the potential for further studies in this area, both with regards to hypothetical process models and demonstration at an appreciably large scale.

\section{Conclusions}

Production of microalgal biomass for high-value applications is a viable business, but lower value bulk products such as fuels and feed still suffer from problems related to low profitability, negative energy balance, and wide-ranging environmental and societal impacts. The use of waste residues or outputs from industrial infrastructure may represent lower-cost, impactful alternatives for supplying nutrients, water, $\mathrm{CO}_{2}$, and heat for microalgal cultivation. Promoting this integration needs research-led demonstration of these processes at large scales for the remaining 


\section{INTEGRATION OF MICROALGAL PRODUCTION WITH INDUSTRY}

engineering and biological issues to be identified and resolved. The end use of the biomass may obviously exclude the use of some of these outputs (nutrients in waste for feed/food production), but for every source that may be prohibited there is likely to be one that is not, due to the diverse range of processes producing nutrient-rich residues.

LCA and TEA, alongside resource assessments, are valuable tools to aid selection and design of the most appropriate technologies and biorefinery scenarios. However, the analyses need to done on a case-by-case basis with as accurate and comprehensive input data as possible. Our intention is that the examples included in this review will aid in LCA inventory data analysis with regards to nutrient, water and $\mathrm{CO}_{2}$ usage and relevant energy inputs for these and processes such as drying. A more unified and considered approach to these assessments will also significantly benefit the field as a whole. ${ }^{20,21}$ For continued investment in this field, these types of analysis need to develop into tools for choosing the appropriate technologies and driving innovation towards more cost-effective and sustainable solutions to advance microalgal production platforms.

\section{Acknowledgments}

The authors would like to thank Dr. Matty Janssen and Dr. Susanne Ekendahl for insightful discussions in the preparation of this work, and the reviewers for their helpful comments. The authors acknowledge funding from the COWI fund (Lyngby, Denmark; grant number HHT/A-127.05/knl) and The Swedish Research Council for Environment, Agricultural Sciences and Spatial Planning (FORMAS; Stockholm, Sweden, BioBUF project, grant number 213-2013-78).

\section{Author Disclosure Statement}

No competing financial interests exist.

\section{REFERENCES}

1. Leu S, Boussiba S. Advances in the production of high-value products by microalgae. Ind Biotechnol 2014;10(3):169-183.

2. Quinn JC, Hoffman J, Pate R, et al. 2015. Economic feasibility and Life Cycle Impact of a turf-scrubber based biorefinery [presentation]. In: Algal Biomass Summit 2015; 2015 Sept. 29-Oct 2; Washington, DC.

3. Jones SB, Zhu Y, Anderson DB, et al. (2014) Process design and economics for the conversion of algal biomass to hydrocarbons: whole algae hydrothermal liquefaction and upgrading. Available at: www.pnnl.gov/main/publications/ external/technical_reports/PNNL-23227.pdf (Last accessed June 2016).

4. Quinn JC, Davis R. The potentials and challenges of algae-based biofuels: A review of the techno-economic, life cycle, and resource assessment modeling. Bioresour Technol 2014;184:444-452.

5. Sills DL, Paramita V, Franke MJ, et al. Quantitative uncertainty analysis of Life Cycle Assessment for algal biofuel production. Environ Sci Technol 2013;47(2):687-694.

6. Zaimes GG, Khanna V. Microalgal biomass production pathways: Evaluation of life cycle environmental impacts. Biotechnol Biofuels 2013;6(1):88.

7. Beal CM, Gerber LN, Sills DL, et al. Algal biofuel production for fuels and feed in a 100-ha facility: A comprehensive techno-economic analysis and life cycle assessment. Algal Res 2015;10:266-279.

8. Canter CE, Blowers P, Handler RM, Shonnard DR. Implications of widespread algal biofuels production on macronutrient fertilizer supplies: Nutrient demand and evaluation of potential alternate nutrient sources. App/ Energ 2015;143:71-80.

9. Taelman SE, De Meester S, Van Dijk W, da Silva V, Dewulf J. Environmental sustainability analysis of a protein-rich livestock feed ingredient in The Netherlands: Microalgae production versus soybean import. Resour Conserv Recycl 2015;101:61-72.

10. Milledge JJ. Commercial application of microalgae other than as biofuels: A brief review. Rev Environ Sci Biotechnol 2010;10(1):31-41.

11. Handler RM, Shonnard DR, Kalnes TN, Lupton FS. Life cycle assessment of algal biofuels: Influence of feedstock cultivation systems and conversion platforms. Algal Res 2014;4:105-115.

12. Huntley ME, Johnson ZI, Brown SL, et al. Demonstrated large-scale production of marine microalgae for fuels and feed. Algal Res 2015;10:249-265.

13. Quinn JC, Smith TG, Downes CM, Quinn C. Microalgae to biofuels lifecycle assessment-Multiple pathway evaluation. Algal Res 2014;4:116-122.

14. Monari C, Righi S, Olsen SI. Greenhouse gas emissions and energy balance of biodiesel production from microalgae cultivated in photobioreactors in Denmark: A life-cycle modeling. J Clean Prod 2016;112:4084-4092.

15. Bennion EP, Ginosar DM, Moses J, Agblevor F, Quinn JC. Lifecycle assessment of microalgae to biofuel: Comparison of thermochemical processing pathways. Appl Energ 2015;154:1062-1071.

16. Andersson V, Broberg Viklund $S$, Hackl R, Karlsson M, Berntsson T. Algaebased biofuel production as part of an industrial cluster. Biomass Bioenerg 2014;71:113-124.

17. Moncada J, Cardona CA, Rincón LE. Design and analysis of a second and third generation biorefinery: The case of castorbean and microalgae. Bioresour Technol 2015;198:836-843.

18. Fortier MOP, Roberts GW, Stagg-Williams SM, Sturm BSM. Life cycle assessment of bio-jet fuel from hydrothermal liquefaction of microalgae. App/ Energ 2014;122:73-82.

19. European Parliament, Council of the European Union. (2009) Directive 2009/ 29/EC. Available at: http://eur-lex.europa.eu/legal-content/EN/TXT/ ?uri=CELEX:32009L0029 (Last accessed June 2016).

20. Collet $P$, Hélias A, Lardon L, Steyer JP, Bernard O. Recommendations for Life Cycle Assessment of algal fuels. Appl Energ 2015;154:1089-1102.

21. Bradley T, Maga D, Antón S. Unified approach to Life Cycle Assessment between three unique algae biofuel facilities. App/ Energ 2015;154:1052-1061.

22. Quinn JC, Catton KB, Johnson S, Bradley TH. Geographical assessment of microalgae biofuels potential incorporating resource availability. Bioenerg Res 2012;6(2):591-600

23. Venteris ER, McBride RC, Coleman AM, Skaggs RL, Wigmosta MS. Siting algae cultivation facilities for biofuel production in the United States: Trade-offs between growth rate, site constructability, water availability, and infrastructure. Environ Sci Technol 2014;48(6):3559-66.

24. Venteris ER, Skaggs RL, Wigmosta MS, Coleman AM. Regional algal biofuel production potential in the coterminous United States as affected by resource availability trade-offs. Algal Res 2014;5:215-225.

25. de Vree JH, Bosma R, Janssen M, Barbosa MJ, Wijffels RH. Comparison of four outdoor pilot-scale photobioreactors. Biotechnol Biofuels 2015; $8(1): 215$

26. Eustance E, Badvipour S, Wray JT, Sommerfeld MR. Biomass productivity of two Scenedesmus strains cultivated semi-continuously in outdoor raceway ponds and flat-panel photobioreactors. J Appl Phycol 2015;28(3)1-13.

27. Chini Zittelli G, Biondi N, Rodolfi L, Tredici MR. (2013) Photobioreactors for mass production of microalgae. In: Richmond A, Hu O, eds. Handbook of Microalgal Culture: Applied Phycology and Biotechnology, Second Edition. John Wiley \& Sons, Ltd, Oxford, UK, 2013;225-266.

28. Williams PJ le B, Laurens LML. Microalgae as biodiesel \& biomass feedstocks: Review $\&$ analysis of the biochemistry, energetics \&t economics. Energ Environ Sci 2010;3(5):554-590. 
29. Robertson DE, Jacobson $S A$, Morgan $F$, et al. A new dawn for industrial photosynthesis. Photosynth Res 2011;107(3):269-277.

30. Slegers PM, Lösing MB, Wijffels $R H$, van Straten $G$, van Boxtel AJB. Scenario evaluation of open pond microalgae production. Algal Res 2013;2(4):358-368.

31. Kenny P, Flynn KJ. In silico optimization for production of biomass and biofuel feedstocks from microalgae. J App/ Phycol 2014;27(1):33-48.

32. Chiaramonti $D$, Prussi $M$, Casini $D$, et al. Review of energy balance in raceway ponds for microalgae cultivation: Re-thinking a traditional system is possible. App/ Energy 2013;102:101-111.

33. de Godos I, Mendoza JL, Acién FG, et al. Evaluation of carbon dioxide mass transfer in raceway reactors for microalgae culture using flue gases. Bioresour Technol 2014;153:307-14.

34. San Pedro A, González-López CV, Acién FG, Molina-Grima E. Outdoor pilot production of Nannochloropsis gaditana: Influence of culture parameters and lipid production rates in raceway ponds. Algal Res 2015;8:205-213.

35. Kumar K, Mishra SK, Shrivastav A, Park MS, Yang JW. Recent trends in the mass cultivation of algae in raceway ponds. Renew Sustain Energ Rev 2015;51:875-885.

36. Eustance E, Wray JT, Badvipour S, Sommerfeld MR. The effects of cultivation depth, areal density, and nutrient level on lipid accumulation of Scenedesmus acutus in outdoor raceway ponds. J Appl Phycol 2015;28(3)1-11.

37. Collet $P$, Hélias $A$, Lardon $L$, et al. Life-cycle assessment of microalgae culture coupled to biogas production. Bioresour Technol 2011;102(1):207-214.

38. Clarens AF, Resurreccion EP, White MA, Colosi LM. Environmental life cycle comparison of algae to other bioenergy feedstocks. Environ Sci Technol 2010;44(5):1813-1819.

39. Rogers JN, Rosenberg JN, Guzman BJ, et al. A critical analysis of paddlewheeldriven raceway ponds for algal biofuel production at commercial scales. Algal Res 2014;4:76-88.

40. Campbell PK, Beer T, Batten D. Life cycle assessment of biodiesel production from microalgae in ponds. Bioresour Technol 2011;102(1):50-56.

41. Kadam K. Environmental implications of power generation via coalmicroalgae cofiring. Energy 2002;27(10):905-922.

42. Brentner LB, Eckelman MJ, Zimmerman JB. Combinatorial life cycle assessment to inform process design of industrial production of algal biodiesel. Environ Sci Technol 2011;45(16):7060-7067.

43. Lardon L, Hélias A, Sialve B, Steyer JP, Bernard O. Life-Cycle Assessment of biodiesel production from microalgae. Environ Sci Technol 2009;43(17):6475-6481.

44. Mendoza JL, Granados MR, de Godos I, et al. Oxygen transfer and evolution in microalgal culture in open raceways. Bioresour Technol 2013;137:188-95.

45. Olivares J. (2010) National Alliance for Advanced Biofuels and Bioproducts Synopsis (NAABB) Final Report. Available at: http://energy.gov/eere/bioenergy/ downloads/national-alliance-advanced-biofuels-and-bioproducts-synopsisnaabb-final (Last accessed December 2015).

46. Jorquera O, Kiperstok A, Sales EA, Embiruçu M, Ghirardi ML. Comparative energy life-cycle analyses of microalgal biomass production in open ponds and photobioreactors. Bioresour Technol 2010;101(4):1406-1413.

47. Adesanya VO, Cadena E, Scott SA, Smith AG. Life cycle assessment on microalgal biodiesel production using a hybrid cultivation system. Bioresour Technol 2014;163:343-355.

48. Stephenson AL, Kazamia E, Dennis JS, et al. Life-Cycle assessment of potential algal biodiesel production in the United Kingdom: A comparison of raceways and air-lift tubular bioreactors. Energ Fuel 2010;24(7):4062-4077.

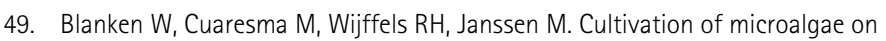
artificial light comes at a cost. Algal Res 2013;2(4):333-340.

50. ClearAs Inc. (2015) The ABNR Process. Available at: http://clearaswater.com/ solution/process (Last accessed March 2016).

51. AstaReal AB. (2015) Products-AstaReal. Available at www.astareal.se/ products (Last accessed July 2015).
52. Sevigné Itoiz E, Fuentes-Grünewald C, Gasol CM, et al. Energy balance and environmental impact analysis of marine microalgal biomass production for biodiesel generation in a photobioreactor pilot plant. Biomass Bioenerg 2012;39:324-335.

53. Milledge JJ, Heaven S. A review of the harvesting of micro-algae for biofuel production. Rev Environ Sci Biotechnol 2012;12(2):165-178.

54. Weschler MK, Barr WJ, Harper WF, Landis AE. Process energy comparison for the production and harvesting of algal biomass as a biofuel feedstock. Bioresour Technol 2014;153:108-115.

55. Adams C, Godfrey V, Wahlen B, Seefeldt L, Bugbee B. Understanding precision nitrogen stress to optimize the growth and lipid content tradeoff in oleaginous green microalgae. Bioresour Technol 2013;131:188-194.

56. Grobbelaar J. 2003. Algal nutrition-Mineral Nutrition. In: Richmond A, ed. Handbook of Microalgal Culture: Biotechnology and Applied Phycology. London, UK: Blackwell Science, 2004;97-115.

57. Powell N, Shilton AN, Pratt $S$, Chisti Y. Factors influencing luxury uptake of phosphorus by microalgae in waste stabilization ponds. Environ Sci Technol 2008;42(16):5958-5962.

58. Mayers JJ, Flynn KJ, Shields RJ. Influence of the N: P supply ratio on biomass productivity and time-resolved changes in elemental and bulk biochemical composition of Nannochloropsis sp. Bioresour Technol 2014;169:588-595.

59. Razon LF, Tan RR. Net energy analysis of the production of biodiesel and biogas from the microalgae: Haematococcus pluvialis and Nannochloropsis. Appl Energ 2011;88(10):3507-3514.

60. Pate $R$, Klise $G$, Wu B. Resource demand implications for US algae biofuels production scale-up. App/ Energ 2011;88(10):3377-3388.

61. Geider $R$, La Roche J. Redfield revisited: Variability of $C: N: P$ in marine microalgae and its biochemical basis. Eur J Phycol 2002;37(1):1-17.

62. Procházková G, Brányiková I, Zachleder $\mathrm{V}$, Brányik T. Effect of nutrient supply status on biomass composition of eukaryotic green microalgae. J Appl Phycol 2014;26(3):1359-1377.

63. Food and Agriculture Organization of the United Nations. (2015) World fertilizer trends and outlook to 2018. Available at: www.fao.org/3/ai4324e.pdf (Last accessed September 2015).

64. Rösch C, Skarka J, Wegerer N. Materials flow modeling of nutrient recycling in biodiesel production from microalgae. Bioresour Technol 2012;107:191-9.

65. Cai T, Park SY, Li Y. Nutrient recovery from wastewater streams by microalgae: Status and prospects. Renew Sustain Energ Rev 2013;19:360-369.

66. Delrue F, Álvarez-Díaz P, Fon-Sing S, Fleury G, Sassi JF. The environmental biorefinery: Using microalgae to remediate wastewater, a win-win paradigm. Energies 2016;9(3):132.

67. Handler RM, Canter CE, Kalnes TN, et al. Evaluation of environmental impacts from microalgae cultivation in open-air raceway ponds: Analysis of the prior literature and investigation of wide variance in predicted impacts. Algal Res 2012;1(1):83-92.

68. Mayers JJ, Albers E, Flynn KJ. 2015. An approaching global phosphorus crisis and microalgal biotechnology: A growing problem \& strategies for effective use [presentation]. In: Algal Biomass Summit 2015; 2015 Sept. 29-Oct 2; Washington, DC.

69. Grady CPU, Daigger GT, Love NG, Filipe CDM. Biological Wastewater Treatment, Third Edition. Boca Raton, FL: CRC Press, 2011.

70. Sturm BSM, Lamer SL. An energy evaluation of coupling nutrient removal from wastewater with algal biomass production. App/ Energ $2011 ; 88(10): 3499-3506$.

71. González-Fernández C, Molinuevo-Salces B, Garcia-González MC. Nitrogen transformations under different conditions in open ponds by means of microalgae-bacteria consortium treating pig slurry. Bioresour Technol 2011;102(2):960-966.

72. Ndegwa PM, Hristov AN, Arogo J, Sheffield RE. A review of ammonia emission mitigation techniques for concentrated animal feeding operations. Biosystems Eng 2008;100(4):453-469. 


\section{INTEGRATION OF MICROALGAL PRODUCTION WITH INDUSTRY}

73. Yuan J, Kendall A, Zhang Y. Mass balance and life cycle assessment of biodiesel from microalgae incorporated with nutrient recycling options and technology uncertainties. GCB Bioenerg 2015;7(6):1245-1259.

74. Collos $Y$, Harrison PJ. Acclimation and toxicity of high ammonium concentrations to unicellular algae. Mar Pollut Bull 2014;80(1-2):8-23.

75. Johansson 0 , Wedborg $\mathrm{M}$. The ammonia-ammonium equilibrium in seawater at temperatures between 5 and $25^{\circ} \mathrm{C}$. J Solut Chem 1980;9(1):37-44.

76. Yang J, Xu M, Zhang $X$, et al. Life-cycle analysis on biodiesel production from microalgae: water footprint and nutrients balance. Bioresour Technol 2011;102(1):159-165

77. Batan L, Quinn J, Willson B, Bradley T. Net energy and greenhouse gas emission evaluation of biodiesel derived from microalgae. Environ Sci Technol 2010;44(20):7975-7980

78. Resurreccion EP, Colosi LM, White MA, Clarens AF. Comparison of algae cultivation methods for bioenergy production using a combined life cycle assessment and life cycle costing approach. Bioresour Technol 2012;126:298-306.

79. Liu X, Saydah B, Eranki P, et al. Pilot-scale data provide enhanced estimates of the life cycle energy and emissions profile of algae biofuels produced via hydrothermal liquefaction. Bioresour Technol 2013;148:163-171.

80. Medeiros DL, Sales EA, Kiperstok A. Energy production from microalgae biomass: carbon footprint and energy balance. J Clean Prod 2014;96:493-500.

81. Guieysse B, Béchet $\mathrm{Q}$, Shilton A. Variability and uncertainty in water demand and water footprint assessments of fresh algae cultivation based on case studies from five climatic regions. Bioresour Technol 2013;128:317-23.

82. Cooney MJ, Young G, Pate R. Bio-oil from photosynthetic microalgae: Case study. Bioresour Technol 2011;102(1):166-177.

83. Chowdhury R, Viamajala S, Gerlach R. Reduction of environmental and energy footprint of microalgal biodiesel production through material and energy integration. Bioresour Technol 2012;108:102-111.

84. Ventura J-RS, Yang $B$, Lee $Y-W$, Lee $K_{1}$ Jahng D. Life cycle analyses of $\mathrm{CO}_{2}$, energy, and cost for four different routes of microalgal bioenergy conversion. Bioresour Technol 2013;137:302-310.

85. Frank ED, Han J, Palou-Rivera I, Elgowainy A, Wang MO. (2011) Life Cycle Analysis of algal lipid fuels with the GREET model. Available at: https:// greet.es.anl.gov/files/algal-lipid-fuels (Last accessed June 2016).

86. Zhang TY, Yu Y, Wu YH, Hu HY. Inhibitory effects of soluble algae products (SAP) released by Scenedesmus sp. LX1 on its growth and lipid production. Bioresour Technol 2013;146:643-648.

87. Erkelens M, Ball AS, Lewis DM. The influences of the recycle process on the bacterial community in a pilot scale microalgae raceway pond. Bioresour Technol 2014;157:364-367.

88. Rodolfi L, Zittelli GC, Barsanti L, Rosati G, Tredici MR. Growth medium recycling in Nannochloropsis sp. mass cultivation. Biomol Eng 2003;20(46):243-248.

89. González-López C V, Cerón-Garcia MC, Fernández-Sevilla JM, et al. Medium recycling for Nannochloropsis gaditana cultures for aquaculture. Bioresour Technol 2013;129:430-438.

90. Gerardo ML, Oatley-Radcliffe DL, Lovitt RW. Integration of membrane technology in microalgae biorefineries. J Memb Sci 2014;464:86-99.

91. Kim DG, La HJ, Ahn CY, Park YH, Oh HM. Harvest of Scenedesmus sp. with bioflocculant and reuse of culture medium for subsequent high-density cultures. Bioresour Technol 2011;102(3):3163-3168.

92. Rwehumbiza VM, Harrison R, Thomsen L. Alum-induced flocculation of preconcentrated Nannochloropsis salina: Residual aluminium in the biomass, FAMEs and its effects on microalgae growth upon media recycling. Chem Eng J 2012;200-202:168-175.

93. Fon Sing $\mathrm{S}$, Isdepsky A, Borowitzka MA, Lewis DM. Pilot-scale continuous recycling of growth medium for the mass culture of a halotolerant Tetraselmis sp. in raceway ponds under increasing salinity: A novel protocol for commercial microalgal biomass production. Bioresour Technol 2014;161:47-54.

94. White $R L$, Ryan RA. Long-term cultivation of algae in open-raceway ponds: Lessons from the field. Ind Biotechnol 2015;11(4):213-220.

95. Penman HL. Natural evaporation from open water, bare soil and grass. Proc $R$ Soc A Math Phys Eng Sci 1948;193(1032):120-145.

96. Béchet Q, Shilton A, Park JBK, Craggs RJ, Guieysse B. Universal temperature model for shallow algal ponds provides improved accuracy. Environ Sci Technol 2011;45(8):3702-3709.

97. Pires JCM, Alvim-Ferraz MCM, Martins FG, Simões M. Carbon dioxide capture from flue gases using microalgae: Engineering aspects and biorefinery concept. Renew Sustain Energy Rev 2012;16(5):3043-3053.

98. Van Den Hende S, Vervaeren H, Boon N. Flue gas compounds and microalgae: (Bio-) chemical interactions leading to biotechnological opportunities. Biotechnol Adv 2012;30(6):1405-1424.

99. Negoro M, Shioji N, Miyamoto K, Micira Y. Growth of microalgae in high $\mathrm{CO}_{2}$ gas and effects of SOx and NOx. Appl Biochem Biotechnol 1991;2829(1):877-886.

100. Laws, E. 1990. Mass culture of algae using carbon dioxide from stack gases [dissertation]. Honolulu, HI: Hawaii University.

101. Negoro $M$, Hamasaki $A$, Ikuta $Y$, et al. Carbon dioxide fixation by microalgae photosynthesis using actual flue gas discharged from a boiler. App/ Biochem Biotechnol 1993;39-40(1):643-653.

102. Cheng J, Yang $Z$, Huang $Y$, et al. Improving growth rate of microalgae in a $1191 \mathrm{~m}^{2}$ raceway pond to fix $\mathrm{CO}_{2}$ from flue gas in a coal-fired power plant. Bioresour Technol 2015;190:235-241.

103. Rickman M, Pellegrino J, Hock J, Shaw S, Freeman B. Life-cycle and technoeconomic analysis of utility-connected algae systems. Algal Res 2013;2(1):59-65.

104. Last GV, Schmick MT. (2011) Identification and selection of major carbon dioxide stream compositions. Available at: www.pnnl.gov/main/publications/ external/technical_reports/PNNL-20493.pdf (Last accessed June 2016).

105. Olaizola M. Microalgal removal of $\mathrm{CO}_{2}$ from flue gases: Changes in medium $\mathrm{pH}$ and flue gas composition do not appear to affect the photochemical yield of microalgal cultures. Biotechnol Bioprocess Eng 2003;8(6):360-367

106. Coleman AM, Wigmosta MS, Langholtz MH, et al. National supply curves for algae biomass: Resource-based collocation [presentation]. In: Algal Biomass Summit 2015; 2015 Sept. 29-Oct 2; Washington, DC.

107. Soletto $D$, Binaghi $L$, Ferrari $L$, et al. Effects of carbon dioxide feeding rate and light intensity on the fed-batch pulse-feeding cultivation of Spirulina platensis in helical photobioreactor. Biochem Eng J 2008;39(2):369-375.

108. Solovchenko A, Solovchenko 0, Khozin-Goldberg I, et al. Probing the effects of high-light stress on pigment and lipid metabolism in nitrogen-starving microalgae by measuring chlorophyll fluorescence transients: Studies with a $\Delta 5$ desaturase mutant of Parietochloris incisa (Chlorophyta, Trebouxiophyceae). Algal Res 2013;2(3):175-182.

109. Douskova I, Doucha J, Livansky K, et al. Simultaneous flue gas bioremediation and reduction of microalgal biomass production costs. Appl Microbiol Biotechnol 2008;82(1):179-185.

110. European Integrated Pollution Prevention and Control Bureau. (2006) Best available techniques reference document on large combustion plants. Available at: http://eippcb.jrc.ec.europa.eu/reference/BREF/Icp_bref_0706.pdf (Last accessed January 2016).

111. Lara-Gil JA, Alvarez MM, Pacheco A. Toxicity of flue gas components from cement plants in microalgae $\mathrm{CO}_{2}$ mitigation systems. J Appl Phycol 2013;26(1):357-368.

112. Stewart JJ, Bianco CM, Miller KR, Coyne KJ. The marine microalga, Heterosigma akashiwo, converts industrial waste gases into valuable biomass. Front Energy Res 2015;3. 


\section{MAYERS ET AL.}

113. Clarens AF, Nassau H, Resurreccion EP, White MA, Colosi LM. Environmental impacts of algae-derived biodiesel and bioelectricity for transportation. Environ Sci Technol 2011;45(17):7554-7560.

114. International Energy Agency GHG R\&D Programme. (2006) Environmental impact of solvent scrubbing of $\mathrm{CO}_{2}$. Available at: www.ieaghg.org/docs/ General_Docs/Reports/2006-14 Environmental Impact of Solvent Scrubbing of C02.pdf (Last accessed February 2016).

115. Duan $L$, Chen $X$, Yang $Y$. Study on a novel process for $\mathrm{CO}_{2}$ compression and liquefaction integrated with the refrigeration process. Int J Energy Res 2013;37(12):1453-1464.

116. Weidema BP, Bauer $C$, Hischier R, et al. (2013). The ecoinvent database: Overview and methodology, Data quality guideline for the ecoinvent database version 3. Available at: www.ecoinvent.org (Last accessed July 2016).

117. US Energy Information Administration. Table 5.6A Average price of electricity to ultimate customers by end-use sector, by State, December 2015 and 2014. Available at https://www.eia.gov/electricity/monthly/ epm_table_grapher.cfm?t=epmt_5_6_a (last accessed March 2016).

118. Klemeš JJ. Handbook of process integration: Minimisation of energy and water use, waste and emissions. Cambridge, UK: Woodhead Publishing Ltd, 2013.

119. Bosma R, de Vree JH, Slegers PM, et al. Design and construction of the microalgal pilot facility AlgaePARC. Algal Res 2014;6:160-169.

120. Sánchez E, Ojeda K, El-Halwagi M, Kafarov V. Biodiesel from microalgae oil production in two sequential esterification/transesterification reactors: Pinch analysis of heat integration. Chem Eng J 2011;176-177:211-216.

121. Ammar $Y$, Joyce $S$, Norman $R$, Wang $Y$, Roskilly AP. Low grade thermal energy sources and uses from the process industry in the UK. Appl Energ 2012;89(1):3-20.

122. Berntsson T, Åsblad A. (2015) Industrial Excess Heat Recovery-Technologies and Applications. Final report-Phase 1. Available at: www.ieaindustry. org/ ongoing-annexes/annex-15.html (Last accessed March 2016).

123. Broberg Viklund S. Energy efficiency through industrial excess heat recoveryPolicy impacts. Energy Efficiency 2015;8(1):19-35.

124. Brueckner S, Miró L, Cabeza LF, Pehnt M, Laevemann E. Methods to estimate the industrial waste heat potential of regions-A categorization and literature review. Renew Sustain Energ Rev 2014;38:164-171.

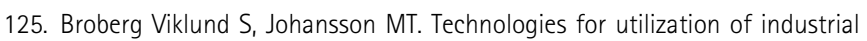
excess heat: Potentials for energy recovery and $\mathrm{CO}_{2}$ emission reduction. Energ Convers Manag 2014;77:369-379.

126. Béchet $\mathrm{O}$, Shilton $A$, Fringer OB, Muñoz R, Guieysse B. Mechanistic modeling of broth temperature in outdoor photobioreactors. Environ Sci Technol 2010;44(6):2197-2203.

127. Li WKW. (1980) Temperature adaptation in phytoplankton: Cellular and photosynthetic characteristics. In: Falkowski $\mathrm{P}$, eds. Primary Productivity in the Sea. New York: Springer US, 19:259-279.

128. Laamanen CA, Shang $H$, Ross GM, Scott JA. A model for utilizing industrial off-gas to support microalgae cultivation for biodiesel in cold climates. Energ Convers Manag 2014;88:476-483.
129. Waller $P$, Ryan $R$, Kacira $M$, Li $P$. The algae raceway integrated design for optimal temperature management. Biomass Bioenerg 2012;46:702-709.

130. Huesemann MH, Edmundson SJ, Wigmosta MS, Brown L. (2015) Increasing annual microalgal biomass productivity through crop rotation: Characterization and modeling of winter and summer strains [presentation]. In: Algal Biomass Summit 2015; 2015 Sept. 29-0ct 2; Washington, DC.

131. Smith VH, McBride RC, Shurin JB, et al. Crop diversification can contribute to disease risk control in sustainable biofuels production. Front Ecol Environ 2015;13(10):561-567.

132. Song $C_{\text {, Liu }} \mathrm{Q}_{\text {, Ji }} \mathrm{N}$, et al. Intensification of microalgae drying and oil extraction process by vapor recompression and heat integration. Bioresour Technol 2016;207:67-75.

133. Acién FG, Fernández JM, Magán JJ, Molina E. Production cost of a real microalgae production plant and strategies to reduce it. Biotechnol Adv 2012;30(6):1344-1353.

134. Xu L, Wim Brilman DWF, Withag JAM, Brem G, Kersten S. Assessment of a dry and a wet route for the production of biofuels from microalgae: Energy balance analysis. Bioresour Technol 2011;102(8):5113-5122.

135. Dong $T$, Knoshaug EP, Davis $R$, et al. Combined algal processing: A novel integrated biorefinery process to produce algal biofuels and bioproducts. Algal Res 2016;doi:10.1016/j.algal.2015.12.021.

136. Laurens LML, Nagle N, Davis R, et al. Acid-catalyzed algal biomass pretreatment for integrated lipid and carbohydrate-based biofuels production. Green Chem 2015;17(2):1145-1158.

137. Fagernäs L, Brammer J, Wilén C, Lauer M, Verhoeff F. Drying of biomass for second generation synfuel production. Biomass Bioenerg 2010;34(9): 1267-1277.

138. Aziz M, Oda T, Kashiwagi T. Integration of energy-efficient drying in microalgae utilization based on enhanced process integration. Energy 2014; 70:307-316.

139. Van Gemert GW. 2009. The Delta dryer: Theoretical and technological development of an energy-efficient dryer for sludge [dissertation]. Delft, The Netherlands: Delft University of Technology

Address correspondence to: Joshua J. Mayers, PhD

Chalmers University of Technology

Department of Biology and Biological Engineering Division of Industrial Biotechnology SE-412 96. Göteborg Sweden

Phone: +4631 7723153

E-mail: joshua.mayers@chalmers.se 